\title{
Rosarichnoides sudeticus igen. et isp. nov. and associated fossils from the Coniacian of the North Sudetic Synclinorium (SW Poland)
}

\author{
Alina CHRZĄSTEK ${ }^{1, *}$, Jolanta MUSZER ${ }^{1}$, Andrzej SOLECKI ${ }^{1}$ and Alfred Marian SROKA ${ }^{2}$ \\ 1 Wrocław University, Institute of Geological Sciences, pl. M. Borna 9, 50-204 Wrocław, Poland \\ 2 Kopalnie Piaskowca Sp. z o.o., Modłowa 1, 59-700 Bolesławiec, Poland
} $10.7306 / g q .1400$

\begin{abstract}
A new ichnogenus and ichnospecies Rosarichnoides sudeticus is proposed for a large, exceptionally well-preserved crustacean burrow, which has been found in the Upper Cretaceous (Coniacian) Quadersandstein of the North Sudetic Synclinorium (Czaple Quarry). Some of its specimens have been assigned to Thalassinoides saxonicus (Geinitz, 1842). It is unbranched, a characteristic rosary-shaped trace fossil, which consists of alternating chambers (swellings) and constrictions. The burrow has no wall, usually lacks ornamentation and has a passive fill. It should be included in the ophiomorphid group sensu Bromley (1996). This unique finding resembles modern crustacean burrows produced by shrimps or crabs. Additionally, Thalassinoides paradoxicus (Woodward, 1830), the starfish Astropecten scupini Andert, 1934, the inoceramids Inoceramus kleini Müller, 1888 and Inoceramus sp. were found in the same sandstones. The trace fossils are indicative of the archetypal Skolithos ichnofacies that is typical of foreshore to middle shoreface settings.
\end{abstract}

Key words: crustacean burrows, Rosarichnoides sudeticus igen. et isp. nov., Thalassinoides, palaeoenvironment, Sudetes, Poland.

\section{INTRODUCTION}

Ichnological studies of ophiomorphids from the Cretaceous deposits of Silesia, Saxony and Bohemia have a very long history, probably since the 18th century (Schulze, 1760) and certainly from the first half of the 19th century (Geinitz, 1842; Göppert, 1842). Incompleteness and different states of preservation, besides the historical uncertainty of what a trace fossil is, led to these trace fossils being classified in different taxonomic groups (as crinoid remains, sponges, algae, foraminifers, trace fossils).

The Ophiomorpha-Thalassinoides-Spongeliomorpha group (Bromley, 1996) or informally named "ophiomorphids group" (Uchman, 1995; Seilacher, 2007) includes crustacean burrows of various architectures, the most typical forming branching tunnel networks, which commonly have swellings. Fürsich (1973) and Schlirf (2000) proposed synonymizing these ichnogenera, but this was not accepted (see Bromley and Frey, 1974; Bromley, 1996; Schlirf, 2005). According to Gibert (1996), Sinusichnus should also be included to this group (see Belaústegui et al., 2014). Gyrolithes Saporta, 1884, Ardelia (Chamberlain and Baer, 1973) and Parmaichnus Pervesler and

\footnotetext{
* Corresponding author, e-mail: alina.chrzastek@uwr.edu.pl

Received: March 20, 2017; accepted: November 8, 2017; first published online: February 1, 2018
}

Uchman, 2009 are also proposed to represent ophiomorphids (Bromley and Frey, 1974; Netto et al., 2007; Seilacher, 2007; Pervesler and Uchman, 2009). Ophiomorpha (Lundgren, 1891) has a characteristic pelleted wall, Spongeliomorpha (Saporta, 1887) shows a criss-cross ornament of sublongitudinal ridges and grooves, which represented abundant wall scratchings, whereas Thalassinoides (Ehrenberg, 1944) refers to a three-dimensional system of burrows, usually unlined or thinly walled. A diagnostic feature of the last ichnogenus is T- or Y-shaped branches. Recently, Hyžný et al. (2015) included the new ichnogenus Egbellichnus to the group of trace fossils made by decapod crustaceans, while Belaústegui et al. (2016) first reported Lepeichnus, which is interpreted as probably produced by crustaceans.

A new type of ophiomorphid specimen has been found in the Upper Cretaceous Quadersandstein (Coniacian) of the North Sudetic Synclinorium. It is the first such large and finely preserved crustacean burrow from the North Sudetic Synclinorium (Fig. 1A) and the Sudetes. It was prepared from a block of sandstone during mining work in the Czaple Quarry B (Fig. 1B) in 1996 by A.M. Sroka and is housed at the Geological Museum of the University of Wrocław (MGUWr 6650s).

Designation of the specimen was made complicated by similarities with some specimens assigned to Thalassinoides saxonicus (Geinitz, 1842), especially those found by German geologists in the 19th century. However, these trace fossils as well as the specimen in question are unbranched. For this reason they should be excluded from Thalassinoides Ehrenberg, 1944 and the proposal of a new ichnogenus seems necessary. 


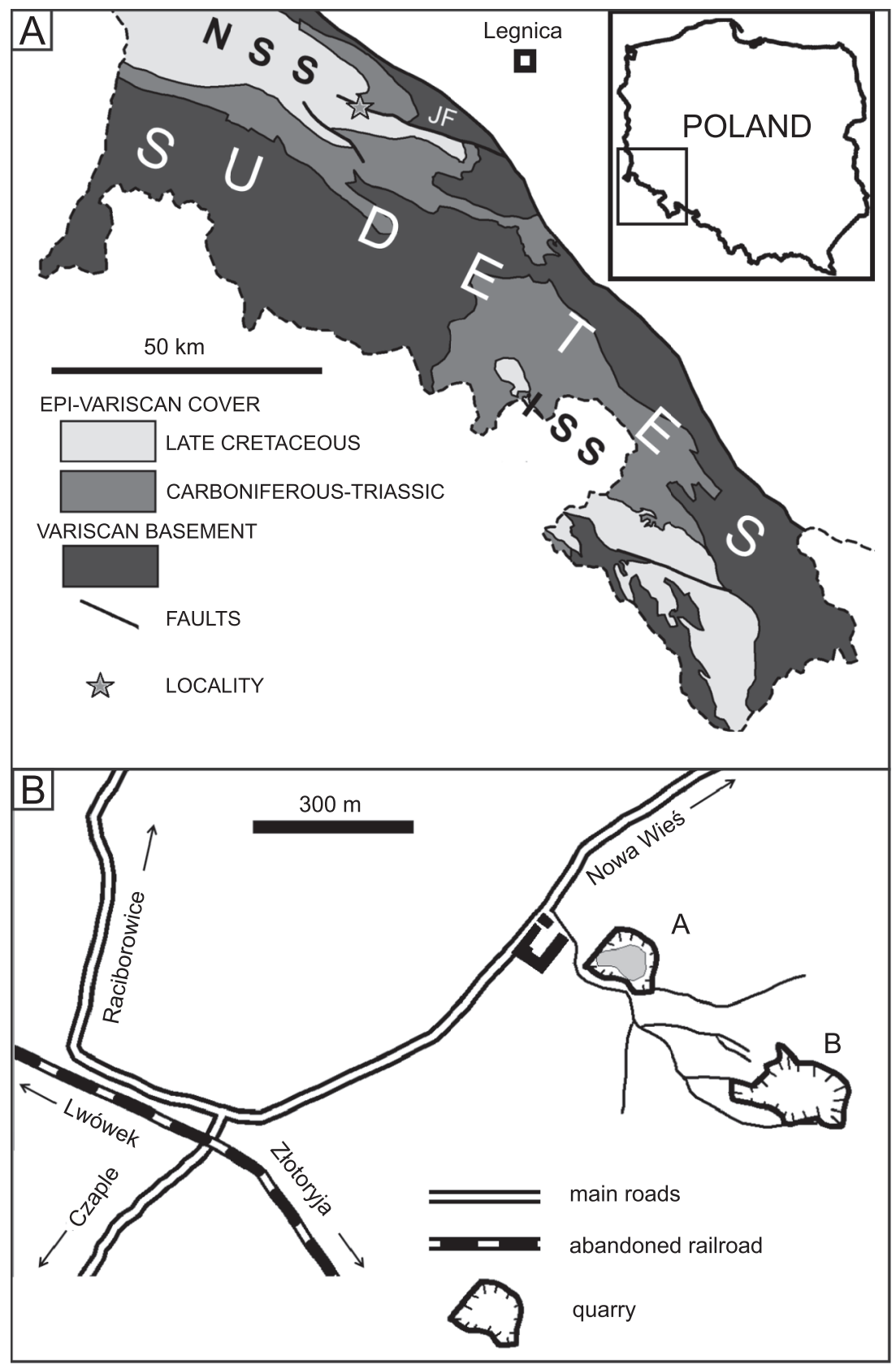

Fig. 1. Location of the study area

A - site under investigation on the map of the current extent of the Late Cretaceous deposits in the Sudetes, NSS - North Sudetic Synclinorium, ISS - Intra Sudetic Synclinorium, JF - Jerzmanice Fault (based on Sawicki, 1967, simplified); B - location of the quarries $\mathrm{A}$ and $\mathrm{B}$ between Czaple and Nowa Wieś

Thalassinoides saxonicus (originally Spongites saxonicus Geinitz, 1842), an exceptionally rare crustacean burrow, was reported mainly from the Upper Cretaceous (Cenomanian, Turonian, Coniacian) of Saxony, Bohemia and Lower Silesia (Geinitz, 1842; Otto, 1852; Frič, 1883; Dettmer, 1912; Andert, 1934). All these authors interpreted $T$. saxonicus as a sponge. The very similar structure of Cylindrites spongioides Göppert, 1842 , assigned to algae (fucoids), was also reported from these regions (Göppert, 1842, 1847; Dunker, 1856). Some of these specimens are undoubtedly trace fossils. Häntzschel (1962, 1975) and Kennedy (1967) assigned Spongites saxonicus to the trace fossil Thalassinoides and gave a list of its synonyms.
This paper gives a formal description of a new trace fossil, Rosarichnoides sudeticus, on the basis of the significant differences in shape from other ophiomorphids. We compared this specimen with other similar forms illustrated in the published literature and with a part of the Göppert's collection from Saxony, Bohemia, Harz and the Sudetes, which were re-discovered in the Geological Museum of the University of Wrocław. In our opinion some unbranched specimens formerly assigned to $T$. saxonicus should also be included in this new ichnospecies. In this paper other associated trace fossils and body fossils of starfish and inoceramids from the Coniacian of the North Sudetic Synclinorium (Czaple, Żerkowice quarries) are also de- 


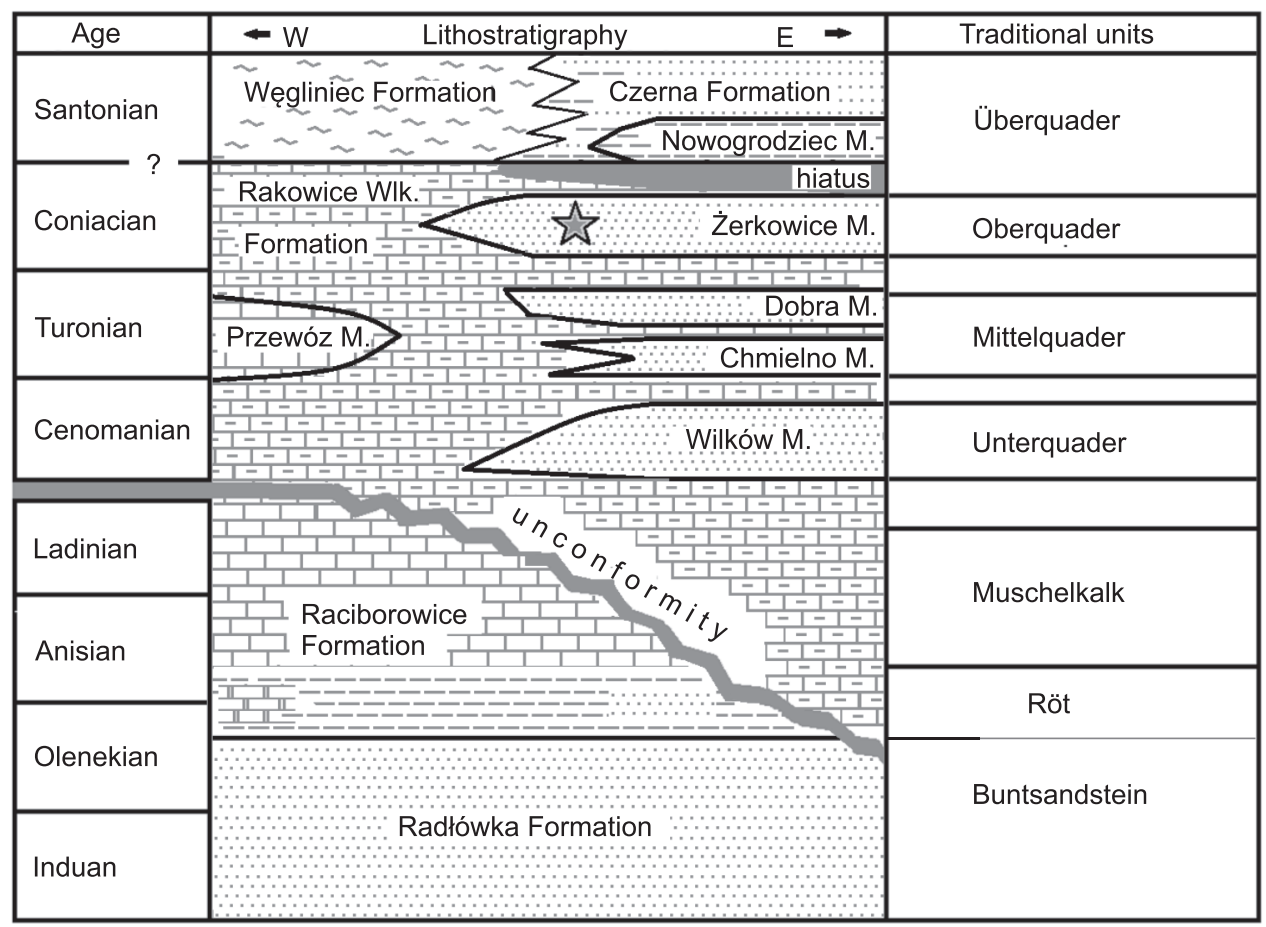

Fig. 2. Stratigraphic position of the site under investigation, marked by a star

Lithostratigraphic units after Milewicz (1985) and Leszczyński (2010), modified (without Keuper deposits which occur only in the most NW part of the NSS), traditional lithostratigraphic units of the Germanic Triassic after Alberti (1834), Beyrich (1849, 1855), Noetling (1880), Scupin (1907, 1912-1913, 1933), Holdefleiss (1915), Beyer (1933), correlation with age units after Lepper et al. (2002), Menning et al. (2012) and Chrząstek (2013a)

scribed. On the basis of the fossils collected, some interpretation of the depositional environment is made.

\section{GEOLOGICAL SETTING}

The sites studied are located in the central part of the North Sudetic Synclinorium (NSS) south of the WNW-ESE trending Jerzmanice Fault (Fig. 1A). The study was conducted in two quarries in the Coniacian sandstones near Czaple and Nowa Wieś villages (Fig. 1B).

The North Sudetic Basin (NSB) is a post-Variscan basin located within the northern Sudetic Foreland above the low-grade Kaczawa Metamorphic Unit (Baranowski et al., 1990). It forms the southeastern prolongation of the East Brandenburg Basin (Musstow, 1968). After the Cretaceous, tectonic inversion of the NSB took place and the North Sudetic Synclinorium was formed (Solecki, 1994).

The Pennsylvanian-Triassic part of the NSB infill includes detrital continental deposits of Rotliegend facies with abundant Early Permian bimodal volcanic rocks (Baranowski et al., 1990). These are overlain by Upper Permian marine marls, carbonates and evaporites (Zechstein facies), followed by Lower Triassic continental Buntsandstein sandstones. The Triassic marine transgression resulted in sedimentation of marls, carbonates and evaporites followed by the Middle Triassic Muschelkalk sequence of marls and limestones (Fig. 2). Locally, in the NW part of the basin the Upper Triassic Keuper evaporites are preserved (Milewicz, 1985; Chrząstek, 2002).

The transgressive Upper Cretaceous marine sedimentary sequence overlies the older basement with slight angular un- conformity and a significant hiatus (Fig. 2). In the southern part of the NSS, the Upper Cretaceous marine sedimentary sequence overlies mainly Lower Triassic (Buntsandstein) strata, locally the Rotliegend and rocks of the Kaczawa Metamorphic Unit, while north of the Jerzmanice Fault the Middle Triassic deposits of the Muschelkalk form its basement (Scupin, 1912-1913; Beyer, 1933, 1934; Milewicz, 1997).

The Upper Cretaceous sequence (Rakowice Wielkie Formation sensu Milewicz, 1985, 1997) consists of marine Cenomanian to upper Coniacian (lower Santonian according to Walaszczyk, 2008) marls that locally pass into limestones intercalated by sandstones and mudstones, covered in the eastern part of the study area by the limnic and deltaic deposits of the Czerna Formation (Fig. 2), which are composed of white kaolinitic sandstones intercalated with calcareous kaolinitic clays with lignite. In the more western part of the NSS, shallow marine mudstones of the Węgliniec Formation form the cover of the Rakowice Wielkie Formation (Fig. 2).

According to Walaszczyk (2008), the Cretaceous deposits of the NSB represent a single, major T-R cycle consisting of several minor, unspecified cycles. This is in line with Milewicz's (1997) opinion that the Coniacian-Santonian deposits of the NSB form the top of a regressive phase of a transgressive-regressive cycle. According to Leszczyński (2010), the Czerna and Węgliniec formations represent the final, complex regressive phase of the minor transgressive-regressive cycles.

Sandstones of the Rakowice Wielkie Formation interpreted by Milewicz (1985) as sandy wedges within predominantly marly or even calcareous deposits have been formally divided into the Wilków, Chmielno, Dobra and Żerkowice members. The lowermost Wilków Member and the uppermost Żerkowice 


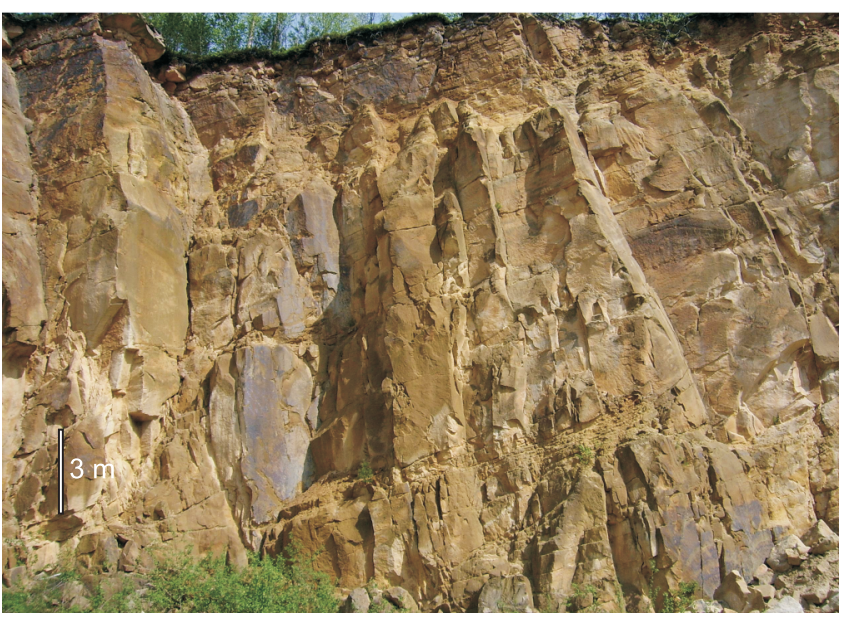

Fig. 3. Coniacian sandstones in the Czaple Quarry B (photo by M. Wypych)

Member correspond to the Unterquader and the Oberquader respectively, of the traditional lithostratigraphy (Fig. 2). The calcareous Przewóz Member occurs in the more western part of the NSS.

Walaszczyk (2008) correlated the boundary between the Rakowice Wielkie Formation and the overlying formations with the middle/upper Coniacian transition and put the Coniacian/Santonian boundary within the Czerna and Weqgliniec formations. In the eastern part of the NSS, a significant hiatus between the Rakowice Wielkie Formation and the Nowogrodziec Member of the Czerna Formation is present (Milewicz, 1956, 1965, 1979, 1997; Walaszczyk, 2008; Leszczyński, 2010).

Leszczyński (2010) studied the Żerkowice Member exposed in the Rakowice Małe and Żerkowice quarries. The Coniacian sandstones of the Żerkowice Member exposed in the Czaple quarries (Figs. 2 and 3 ) are fine to medium-grained arenites (see Leszczyński, 2010). The deposits studied are well-sorted but poorly-rounded (see Milewicz, 1997). Sedimentary structures within them are not easily visible. Parallel lamination, ripple marks and large-scale cross-stratification occur locally. The laminae dip mainly to the south and south-east, towards the shore of the basin (Leszczyński, 2010). The thickness of individual sandstone beds is up to few metres. In their upper part, the sandstones are covered with a limonite crust (see Leszczyński, 2010). According to the author cited, the Coniacian sandstones are interpreted as bar and storm deposits.

A part of the Cretaceous sedimentary sequence has been uplifted and eroded due to tectonic Turonian-Paleogene activity (Solecki, 1994). The present-day remains of the North Sudetic and Intra Sudetic Cretaceous basins originally formed a narrow, shallow marine strait (Scupin, 1910, 1936) being influenced by both the Boreal and Tethyan realms (Fig. 4). The northeastern and southwestern boundaries of this strait are marked by non-depositional areas of the so-called Eastern and Western Sudetic islands, ESI and WSI respectively (Biernacka, 2012). From the palaeogeographic point of view, the sites under investigation were located at the northwestern outlet of a shallow connection where deltaic to shallow marine clastic sedimentation prevailed (Wilmsen et al., 2014).

\section{DESCRIPTION OF THE TRACE FOSSILS}

Rosarichnoides igen. nov.

Derivation of $\mathrm{n}$ a m e. - After the rosary-shaped form in which the type ichnospecies occurs, Greek ichnos = trace, and -oides - after ancient Greek "likeness".

Ty p e i c h n o s p e c i e s. - Rosarichnoides sudeticus isp. nov., type and only known ichnospecies.

$\mathrm{D}$ i a g $\mathrm{n}$ o s i s. - A rosary-shaped and unbranched structure, which consists of regularly and alternately placed chambers (swellings) and constrictions. Chambers are spherical, elongated to pear-shaped. The burrow is without any wall and has a passive, structureless fill, similar to the host sediment. The surface of the burrow is unornamented, and rough rather than smooth.

Comparison with other ichnogenera.Rosarichnoides morphologically resembles ophiomorphids in comprising tunnels with swellings ('turn-arounds'). The presence of large swellings (diameter up to $7 \mathrm{~cm}$ ), a passive fill and lack of a wall are similar to Thalassinoides saxonicus (Geinitz, 1842). By contrast with the characteristic T- or Y-shaped branchings of Thalassinoides (e.g., Myrow, 1995), Rosarichnoides is unbranched. The only very large Thalassinoides saxonicus was recently reported by Göhler (2011a, b) from the Cenomanian of Saxony (Germany), illustrated mainly by drawings. Its dimensions, especially of the swollen chamber (up to $7 \mathrm{~cm}$ ), are similar to those of our specimen. It differs from Rosarichnoides in having branches and a single swelling at the end of the tunnel. In comparison to Ophiomorpha Lundgren, 1891, the new ichnogenus does not have a pelleted wall (see Frey et al., 1978). Rosarichnoides also does not possess as abundant scratches (distinctive, longitudinal ridges) as does Spongeliomorpha Saporta, 1887.

This new ichnogenus shows some similarities to Type II (multiple-resting-place type) specimens of Psilonichnus quietis Myint, 2001 in having swollen chambers connecting with tunnels (Myint, 2001: fig. 2B). The swellings of this Psilonichnus have four different shapes (Myint, 2001: fig. 5), but only one of them (Myint, 2001: fig. 5B) resembles swellings of Rosarichnoides. However, in comparison to the oval to pear-shaped chambers of Rosarichnoides, this type of swelling in Psilonichnus is distinctly semi-triangular shaped (e.g., Myint, 2001: figs. 11, 14A; 2009: fig. 2). In addition, these swellings are pointed in the same direction and the constrictions of Psilonichnus quietis are much longer than those of Rosarichnoides. On the other hand, the diameter of the new ichnogenus is twice as large as is Psilonichnus quietis.

Regular bulb-shaped swellings also characterize Asterosoma ludwigae Schlirf, 2000, but these radiate from a circular central axis and have internal concentric structures (see Neto de Carvalho and Rodrigues, 2007). Rosarichnoides differs from Asterosoma in having a different orientation and in the shape (pear-shaped) of the swollen chambers, which are structureless.

A similar morphology of the burrow, which consists of a cylindrical tunnel with regularly distributed chambers, is seen in Halimedides Lorenz von Liburnau, 1902. In comparison to 


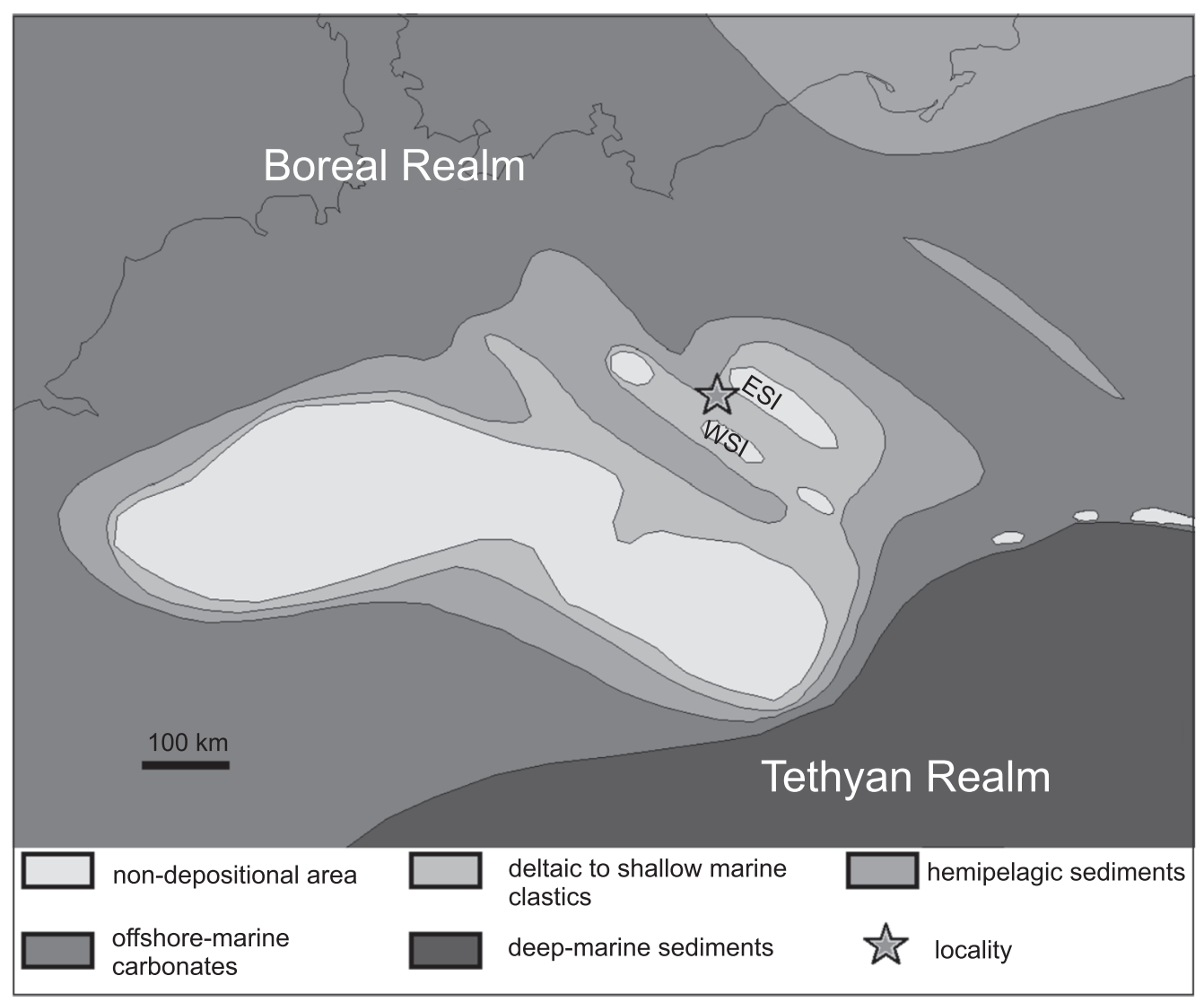

Fig. 4. Palaeogeographic position of the site under investigation (based on Wilmsen et al., 2014, modified)

WSI - Western Sudetic Island, ESI - Eastern Sudetic Island

Rosarichnoides this ichnogenus has heart-shaped chambers (two chambers symmetrically and bilaterally distributed on the both sides of tunnel; see Gaillard and Olivero, 2009: figs. 10, 15-17) and much smaller dimensions (up to $2.5 \mathrm{~mm}$ tunnel diameter, $100 \mathrm{~mm}$ length of tunnel).

A rosary-like trace (resembling pearls) of unknown origin (see Häntzschel, 1975: fig. 43/3; Uchman, 1998: fig. 11) is also seen in Hormosiroidea Schaffer, 1928. This consists of very small hemispherical or spherical chambers (up to $1 \mathrm{~cm}$ ) connected by a horizontal thin string (diameter up to $2 \mathrm{~mm}$ ). It differs from Rosarichnoides not only in dimensions, but also in the different shape of the bulbs, and in the occurrence of additional oblique strings, locally branched, emerging from the chambers. Additionally, the surface of some specimens of Hormosiroidea is coarsely granulose.

Rosarichnoides sudeticus isp. nov.

(Fig. 5A-L)

?partim 1842 Spongites Saxonicus m. Schultze - Geinitz, p. 96, Taf. XXIII, fig. 2.

partim 1852 Spongia saxonica Geinitz (Cylindrites spongioides Göppert) - Otto, p. 20-21, Taf. 6, fig. 1.

?partim 1909 Cylindrites spongioides Goepp. emend. - Richter, p. 8-11, Taf. XI, fig. 1.

Type material and occurrence.- Holotype - one specimen (natural cast of the burrow) figured in Figure 5A and its eight parts figured in Figure 5B-I, a private collection of A.M. Sroka now housed at the Geological Museum of the University of Wrocław (MGUWr 6650s). The specimen has been extracted from an isolated block of medium-grained sandstone in the Czaple Quarry B (Fig. 1B), Coniacian in age, North Sudetic Synclinorium.

De rivation of $n$ a m e. - After the Sudety Mountains, the region where the species was found.

D i a g n o s is. - The burrow consists of asymmetrical, mainly pear-shaped chambers connecting with a tunnel. The constrictions are distinctly shorter than the swellings (chambers). The diameter of the swellings is over twice as large as the diameter of the constrictions. The surface of the trace fossil is rather rough, mostly unornamented, but local sand knobs, furrows and ridges can be present.

$\mathrm{D}$ e s c r i p t i o n. - The orientation of the specimen studied is unfortunately unknown, because it was found in a sandstone block. It comprises a sand-filled burrow, with alternating swellings and constrictions and lacking branches. This large burrow is $127 \mathrm{~cm}$ long, but this is not the total length, because the specimen is broken at both ends. It consists of 8 asymmetrical, spherical to pear-shaped chambers (swellings), $5.6-6.4 \mathrm{~cm}$ across, and constrictions between them, which are 2.06-2.86 cm across (Fig. 5A; Table 1). The chambers are arranged on both sides of the tunnel at different angles (Fig. 5A). Their length (parameter c; Fig. 6) varies from 9.55 to $12.5 \mathrm{~cm}$ (Table 1). The constrictions are $2.6-8.5 \mathrm{~cm}$ long. Parameter b1/a1 varies from 2.2 to 2.8 (Fig. 6; Table 1). The burrow is elliptical or rarely circular in cross-section and its parameter a1/a2 

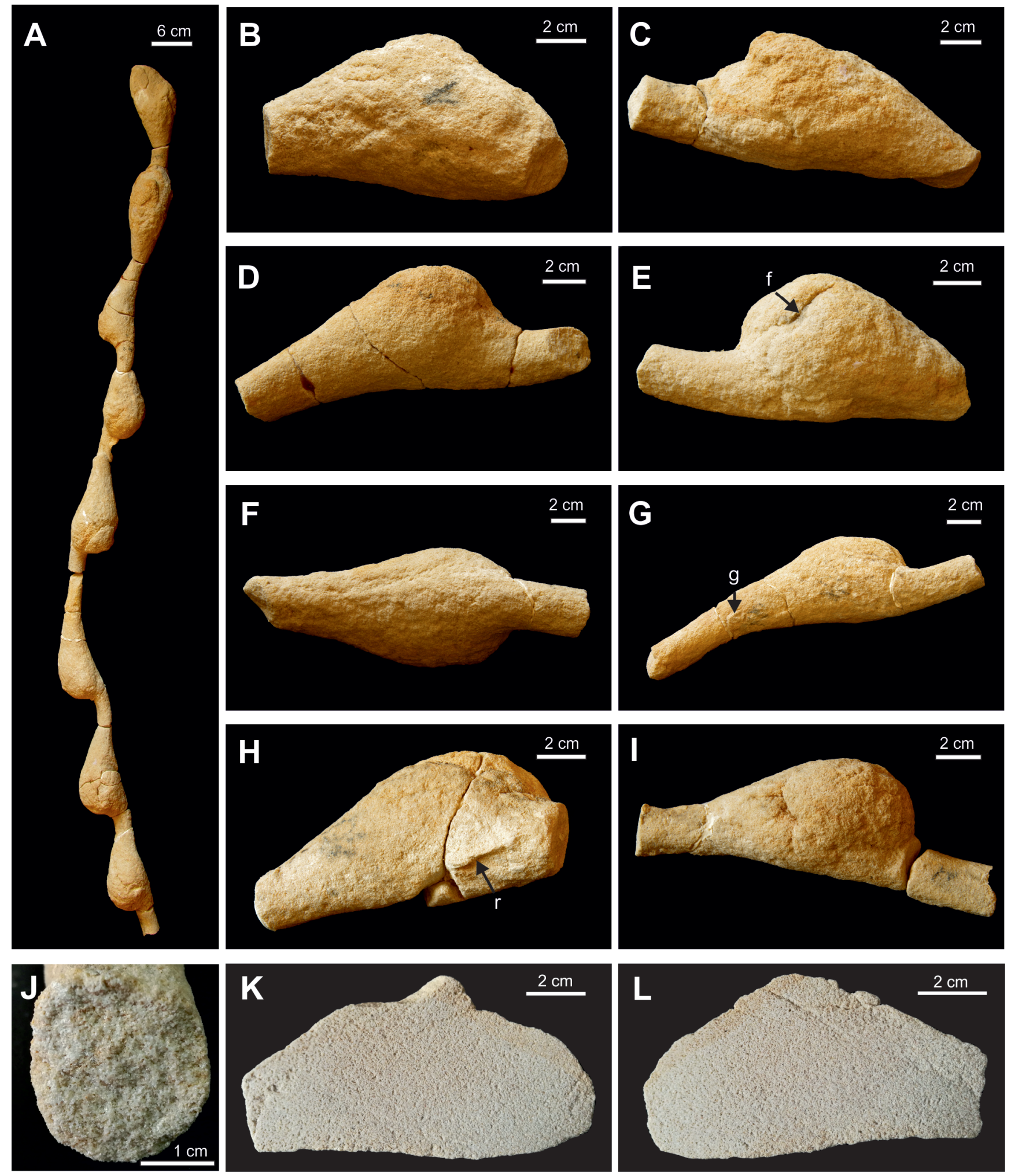

Fig. 5. Rosarichnoides sudeticus igen. et isp. nov. from the Czaple Quarry B, housed at the Geological Museum of the University of Wrocław (MGUWr 6650s)

A - the whole specimen (eight elements); B-I - isolated fragments of Rosarichnoides sudeticus igen. et isp. nov. illustrated in order from 1 (B) to 8 (I); J - cross-section of the constriction (fragment of the burrow shown in Fig. 5I); K, L - longitudinal sections of the swollen chamber illustrated in Figure 5B; $f$ - furrow, $g$ - sand granule $(k n o b), r$ - ridge 
Values of morphometric parameters of Rosarichnoides sudeticus igen. et isp. nov. [cm]

\begin{tabular}{|c|c|c|c|c|c|c|c|c|c|c|c|c|c|}
\hline $\begin{array}{c}\text { No. of } \\
\text { part }\end{array}$ & $\mathrm{a} 1$ & a2 & a3 & a4 & b1 & b2 & C & $\mathrm{d}=\mathrm{b} 1-\mathrm{a} 1$ & I & $\mathrm{a} 1 / \mathrm{a} 2$ & a3/a4 & b1/b2 & b1/a1 \\
\hline 1 & 2.5 & 2.43 & 2.73 & 2.06 & 5.85 & 4.4 & 11.5 & 3.35 & 16 & 1.029 & 1.325 & 1.33 & 2.34 \\
\hline 2 & 2.22 & 2.36 & 2.1 & 2.35 & 5.6 & 5.21 & 12.5 & 3.38 & 21 & 0.941 & 0.894 & 1.075 & 2.5225 \\
\hline 3 & 2.46 & 2.25 & 2.34 & 2.2 & 6.35 & 5.5 & 11.32 & 3.89 & 17.5 & 1.093 & 1.064 & 1.155 & 2.5813 \\
\hline 4 & 2.23 & 2.1 & - & - & 6.4 & 5.75 & 9.55 & 4.17 & 14.17 & 1.062 & - & 1.113 & 2.87 \\
\hline 5 & 2.62 & 2.46 & - & - & 6.02 & 5.08 & 11.62 & 3.4 & 11.62 & 1.065 & - & 1.185 & 2.2977 \\
\hline 6 & 2.5 & 2.36 & 2.64 & 2.38 & 6.06 & 5.7 & 11.84 & 3.56 & 16.2 & 1.059 & 1.109 & 1.063 & 2.424 \\
\hline 7 & 2.86 & 2.45 & 2.23 & 2.37 & 6.24 & 5.38 & 11.6 & 3.38 & 12.5 & 1.167 & 0.941 & 1.16 & 2.1818 \\
\hline 8 & 2.7 & 2.45 & 2.55 & 2.19 & 5.97 & 5.46 & 10.18 & 3.27 & 13.84 & 1.102 & 1.164 & 1.093 & 2.2111 \\
\hline
\end{tabular}

For parameters see Figure 6

varies from 0.94 to 1.17 ; parameter a3/a4 is between $0.89-1.32$ and parameter b1/b2 varies from 1.06 to 1.32 (Table 1; Fig. 6). The burrow is without any wall or lining. The cross-sections of the burrow show that the fill is passive and structureless (Fig. $5 \mathrm{~J}-\mathrm{L}$ ), the same as the host rock. The outer surface is rather rough and usually lacks ornamentation. Four indistinct oval sand knobs (measuring 0.5/0.7 cm; 0.6/1 cm; 0.9/1cm; $0.7 / 1.2 \mathrm{~cm}$ ) have been observed on two swellings (Fig. 5G). On the outer surface of the swellings, rare furrows, $2-5 \mathrm{~cm}$ long, are also present (Fig. 5E). They are variously oriented, mostly obliquely, and they might be poorly preserved scratch traces. Additionally, one short thin "ridge", $3 \mathrm{~cm}$ long and $\sim 2 \mathrm{~mm}$ wide, occurs on the surface of a swelling (Fig. 5H).

D i s c u s s i o n. - Designation of the studied specimen was difficult because the most similar forms were described or illustrated in 19th and at the beginning of the 20th centuries. These forms are incomplete, showing various preservation conditions and were classified in different taxonomic groups. However, part of Göppert's 19th century collection was re-discovered in the Geological Museum of the University of Wrocław, which allowed observation of some details on the real specimens and comparison with the form studied.

Similar forms, undoubtedly trace fossils, probably Thalassinoides, were first described by Schulze (1760: tab. 2, figs. 1-5) as crinoid remains or cavities left by vagile starfish. This ichnotaxon was originally described by Geinitz (1842) as a sponge, Spongites saxonicus. However, only one of his specimens is unbranched and has two spherical swellings (Taf. 23, fig. 2) and the other (Taf. 23, fig. 1) is branched and has a narrow longitudinal ridge on the upper part and a clearer granular ornamentation. The latter specimen was ascribed by Kennedy (1967) to Thalassinoides saxonicus, while the first one was included in Ophiomorpha nodosa. In our opinion, the last assignation should be revised. Geinitz's specimen (tab. 1, fig. 2) is unbranched and has alternating oval swellings and constrictions, similar to Rosarichnoides sudeticus isp. nov., which indicates the affiliation to this ichnogenus.

Granular ornamented forms with swollen and narrowing chambers were also described by Göppert (1842) as the fucoid alga Cylindrites spongioides (tabs. XLVI/1-5; XLVIII/1-2, p. $115)$, but they are undoubtedly ichnofossils. According to Kennedy (1967), Göppert's figures 1-4 in tab. XLVI may show crustacean burrows, possibly Ophiomorpha. We agree with his opinion. Additionally, a part of the Göppert's Wrocław collection, which has not been published, supports this view. Specimens (cat. no. MGUWr - 2883p from Bohemia, MGUWr - 7372p from Saxony, MGUWr - 5648p from Bystrzyca Kłodzka) assigned to Cylindrites spongioides Göpp. have some features of ophiomorphids (Fig. 7A-D). Three of them (2883p - two specimens; 7372p; Fig. 7A, D) are horizontal tunnels (from 2 to $4 \mathrm{~cm}$ across) with Y-shaped bifurcations and granulated walls, which are characteristic of Ophiomorpha (see Bromley and Frey, 1974; Frey et al., 1978). One of them (5648p; Fig. 7B, C) is a fragment of a much thinner tunnel $(1.3 \mathrm{~cm}$ across $), 22 \mathrm{~cm}$ long, with one flat extended chamber $(3.5 \mathrm{~cm}$ across), which displays a poorly visible granulated wall. It is probably Ophiomorpha too. According to many authors (e.g., Gibert and Ekdale, 2010; Wiest et al., 2016). Thalassinoides never possesses pelleted walls. It is not excluded that the difficulties in recognition of these ichnotaxa are caused by the possibility that some of them are transitional forms between Thalassinoides and Ophiomorpha (see Uchman, 1991).

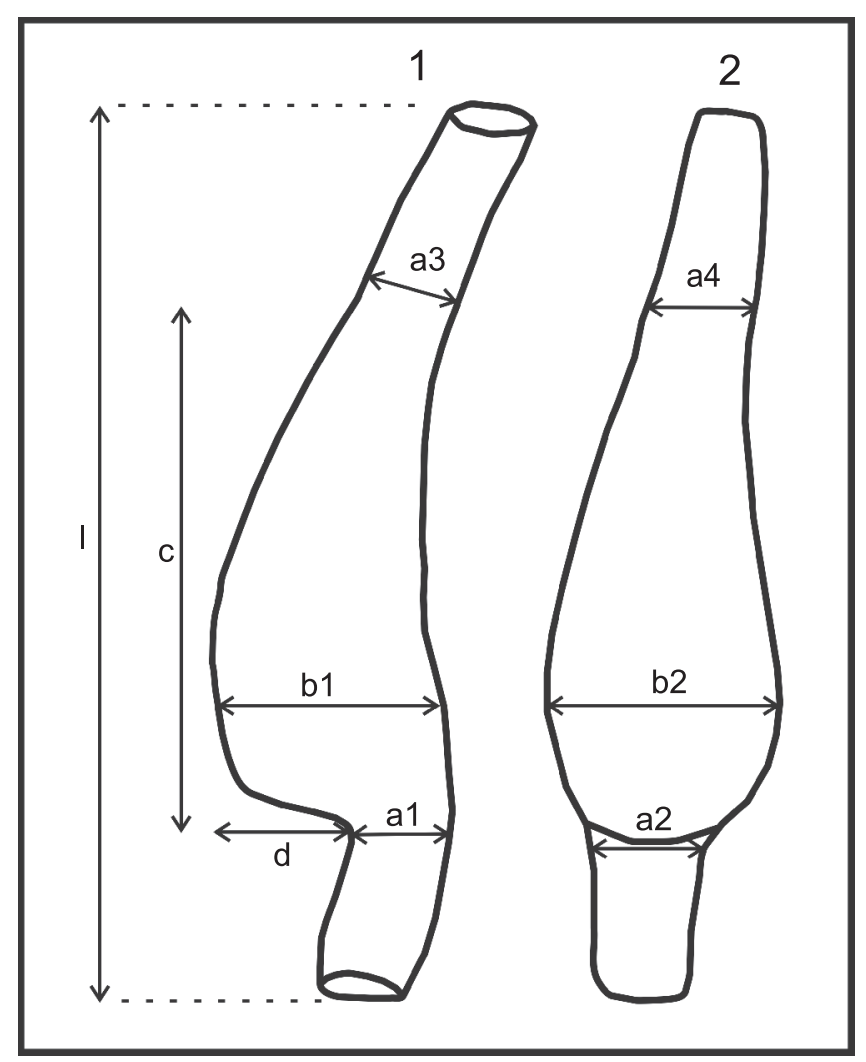

Fig. 6. Drawing of a swollen chamber and constriction of Rosarichnoides sudeticus igen. et isp. nov. and morphometric parameters which have been measured 

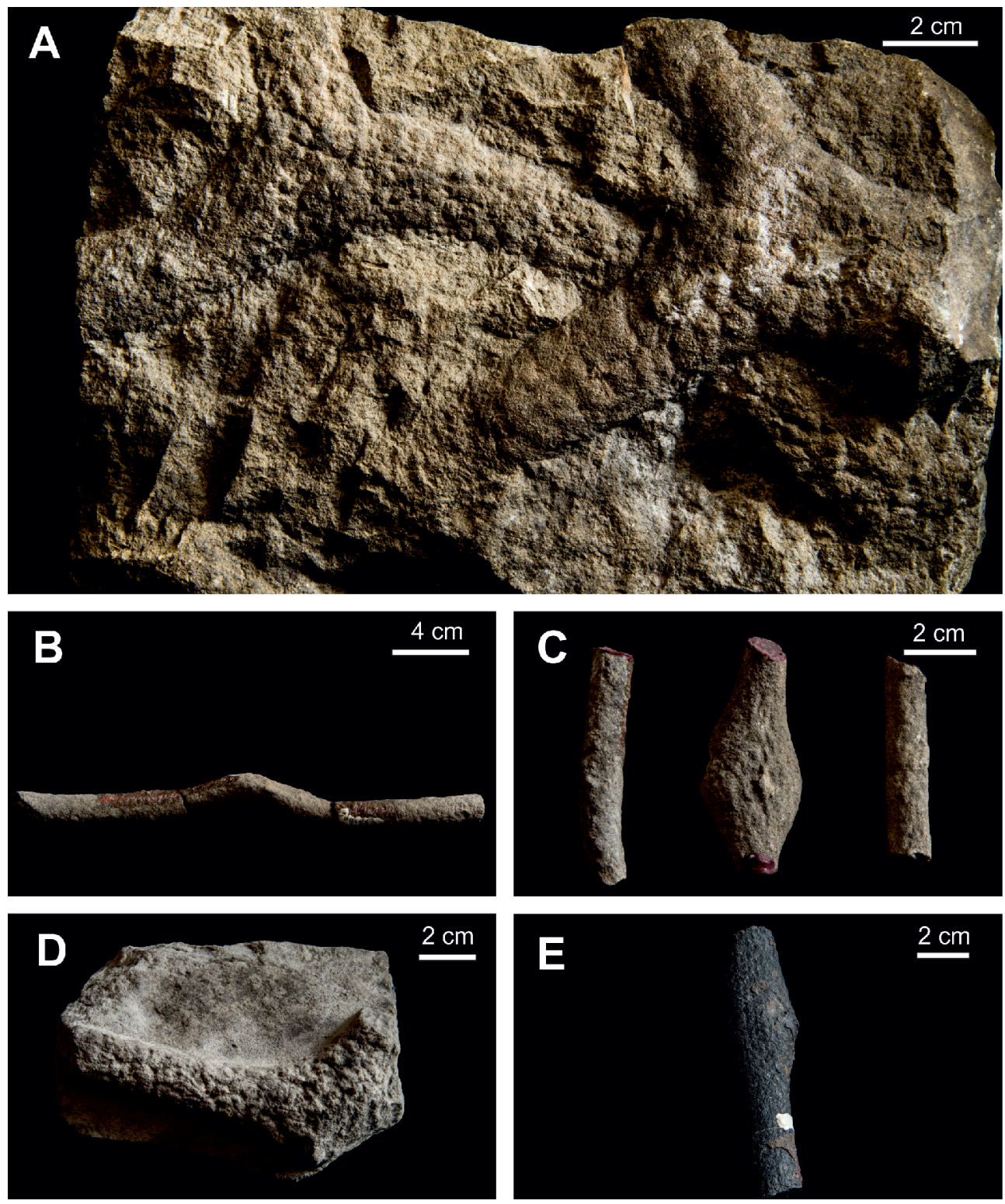

Fig. 7. Specimens from Göppert's collection from the Geological Museum of Wrocław University assigned to Cylindrites spongioides Göppert

Specimens A-D are ophiomorphids (probably Ophiomorpha nodosa), whereas specimen $\mathrm{E}$ is alga; $\mathbf{A}$ - cat. no. MGUWr - 2883p; B, C - MGUWr - 5648p; D - MGUWr - 7372p; E - MGUWr - 5569p

Göppert (1847) described other specimens of Cylindrites spongioides from the Quadersandstein (Turonian) of Bystrzyca Kłodzka. However, they have characteristic plant structures on the surface and in our opinion might be considered as algae; Göppert (1847), in describing fucoids (algae), cited ?Spongites saxonicus. One specimen from Göppert's Wrocław collection from Harz (cat. no. MGUWr - 5569p; Fig. 7E) is similar. It is $10.3 \mathrm{~cm}$ long, $1.7-2.8 \mathrm{~cm}$ across. It has a carbonized wall with a regular structure (alternately arranged knobs), and is probably of plant origin.

Otto (1852: Taf. VI, figs. 1-3) illustrated Spongia saxonica Geinitz (Cylindrites spongioides Göppert) from the Quadersandstein at Banewitz near Dresden. Only his specimen shown in fig. 1 is unbranched, rather smooth and has four spherical swollen chambers. Otto (1852) interpreted it as probably a juvenile form of Spongia saxonica Geinitz. In our opinion this specimen might represent Rosarichnoides sudeticus igen. et isp. nov. Kennedy (1967) cited two other branched Otto specimens illustrated on figures 2 and 3 on Taf. VI as synonyms of Thalassinoides saxonicus (Geinitz).

Dunker (1856) described Cylindrites spongioides (s. 183, Taf. XXXV, fig. 5) as algae from Blankenburg (Harz, Saxony, Germany). This specimen, with granulated swellings, is the most similar to Göppert's forms (1842) and belongs probably to Ophiomorpha.

Unbranched, rather smooth forms similar to Rosarichnoides sudeticus isp. nov., but with only one swollen chamber were reported by Frič (1883) and Dettmer (1912) from the Cretaceous of the Bohemian Basin (the Turonian of Mlada Boleslav) and Saxony (the Cenomanian and Turonian) respectively. Frič (1883) described Spongites saxonicus Gein. (fig. 128) and classified it within the Coelenterata, whereas Dettmer (1912) figured two specimens of Spongites saxonicus Geinitz (=Cylindrites spongioides Göppert; Taf. VIII, figs. 5, 6) and in- 
cluded them within the fucoides (algae). These sketched specimens are fragmentarily preserved and have longer constrictions than swollen chambers. Additionally, the shape of their swollen chambers is slightly different (symmetrical, more spherical than pear-shaped) than the chambers of Rosarichnoides sudeticus. The state of preservation of these specimens does not allow for assignation to Rosarichnoides sudeticus, but they might belong to this ichnogenus. The other Dettmer (1912) specimen of Spongites saxonicus Geinitz (=Cylindrites spongioides Göppert) is branched (Taf. VIII, fig. 4), without swollen chambers, and resembles Thalassinoides.

Počta (1885) described Spongites saxonicus (without any illustrations) as sponges (Ceratospongiae) - "body bulge-shaped or cylindrical, bifurcated with large, elongated swollen nodes from the Kreideformation of Bohemia". This description is in agreement with typical features of Thalassinoides.

Richter (1909) described Cylindrites spongioides Goepp. emend. as plant remains and illustrated them in Taf. XI-XIII, but only figure 1 in Taf. XI might be regarded as probably Rosarichnoides sudeticus igen. et isp. nov., while other three specimens (Taf. XI/fig. 7, Taf. XII/fig. 5, Taf. XIII/6) seem similar to Ophiomorpha as noted by Kennedy (1967). Richter's specimen shown in figure 1 (Taf. $\mathrm{XI}$ ) is unbranched, has a rather rough surface and consists of two pear-shaped swollen chambers connecting with a constricted tunnel, but by contrast with Rosarichnoides the constrictions are longer than the swellings.

Häntzschel (1962) included Spongites saxonicus Geinitz and Cylindrites spongioides Göppert in Ophiomorpha, while Spongites saxonicus Geinitz (nomen nudum), Cylindrites spongioides Goeppert (nom. nud.) and ?Aschemonia Dettmer, 1915 in Thalassinoides. Kennedy (1967) provided a detailed synonymy of Thalassinoides saxonicus, but he incorrectly listed some names, pages or figures in the synonymy list. He designated as lectotype of this ichnospecies one specimen of Spongites saxonicus Geinitz, 1842 (only fig. 1 in Geinitz). The identification of the best specimens of $T$. saxonicus in Kennedy's opinion (Kennedy, 1975: pl. 5, fig. 2; pl. 6, fig. 3) is difficult because they are covered with Chondrites isp. Häntzschel (1975) included Spongites saxonicus Geinitz, 1842 (partim) and Cylindrites spongioides Göppert, 1842 (partim) in Ophiomorpha. Spongites was illustrated by Häntzschel (1975) only by a drawing (fig. 1/74). The author included $T$. saxonicus (Häntzschel, 1975: fig. 70/2b) in Thalassinoides. Worth noticing that fig. 70/2a, described as Thalassinoides sp., is the same as fig. 1/74 illustrated as „Spongites” (see Häntzschel, 1975). In the diagnosis of the ichnogenus, the author cited typical swellings at points of branching or elsewhere. He also noted that rare transitional forms with the tuberculate structure of Ophiomorpha have been described.

The names Spongites and Cylindrites are not available, as they are pre-occupied. The genus Spongites Kützing, 1841 is assigned to algae (see Woelkerling, 1985) and the genus Cylindrites Sowerby, 1824 represents gastropods (Kennedy, 1967; Kollmann, 2002; Morris and Lycett, 2015).

Trace maker and ethology. - The specimen studied resembles modern crustacean burrows. The most complex burrow systems typical of ophiomorphids are produced by members of the decapod infraorders Gebiidea and Axiidea (formerly known as thalassinideans, see Hyžný et al., 2015 and references therein). One of the most characteristic features of these infraorders is the presence of swellings (mostly interpreted as turn-arounds).

A classification of "thalassinidean" shrimp burrows based on morphological and ecological characteristics was proposed by Griffis and Suchanek (1991). Geometrically Rosarichnoides sudeticus igen. et isp. nov. shows similarities to Type 2 (simple branches) made by deposit feeders, which produce mounds of sediment at their opening and usually do not store seagrass in burrow chambers. This type of burrow is a simple, twisting shaft, vertically oriented, with swollen chambers. In the upper part of the burrow a Y-shaped connection to the sediment surface is observed (Griffis and Suchanek, 1991). This last feature is missing in our material, probably due to its incompleteness. Though the position of the specimen studied is unknown, it is not excluded that it was vertically oriented. The Griffis and Suchanek (1991) generalized model was criticized by some authors (Dworschak and Ott, 1993; Nickell and Atkinson, 1995; Gibert and Ekdale, 2010; Hyžný et al., 2015) due to some features, such as the lack of mounds at the openings and number of openings in the fossil record and the difficulty of assigning certain species to a burrow type.

Ethologically, Rosarichnoides igen. et isp. nov. represents a fodinichnion, however an agrichnion is not excluded. It seems that it is a record of a simple process of burrowing through sediments in search for food. Nevertheless such numerous and regularly distributed swollen chambers suggest the possibility of the storage of seagrass or algae, or even of gardening behaviour on the burrow chamber walls. However, there is no other evidence for these behaviours. Most callianassids are assumed to be deposit feeders and in this case they create complicated burrow systems (Hyžný and Klompmaker, 2015 and references therein). Studies on modern crustaceans (e.g., Stamhuis et al., 1996) show that they usually represent a mixture of feeding strategies.

The tracemaker of the new ichnogenus was rather a deposit or detritus feeder, which probably could leave the burrow to collect organic material for later consumption. The possible producer of this burrow was a decapod crustacean (ghost or mud shrimp or crab). According to Griffis and Suchanek (1991), 72\% of the "Callianassa" species (infraorder Axiidae) construct Type 2 (simple branches) of the burrows. Some of the contemporary mud shrimp burrows studied by Sepahvand et al. (2014) show a similar morphology to Rosarichnoides (a single oblique shaft with multiple turning chambers - see fig. 4 therein). Their producer is the gebiidean Upogebia carinicauda, the burrows of which vary depending on the habitat type and on the physical characteristics of the sediments. According to Hyžný (2011) members of the Gebiidea and Axiidea are known to construct very complex burrow systems which can reach $>1 \mathrm{~m}$ in depth. Some resemblance to the semitriangular swellings of Type II of Psilonichnus quietis Myint, 2001 (see fig. 5B therein), which was produced by deposit feeding/or scavending brachyuran crabs, also suggest these organisms as the potential tracemakers of Rosarichnoides.

The role of the swollen chambers in crustacean burrowing has been discussed by many authors (e.g., D'Alessandro and Bromley, 1995; Stamhuis et al., 1996; Dworschak, 2001; Lewy and Goldring, 2006). Swellings are mainly interpreted as turn-arounds, where a tracemaker could change its direction of movement. Other ethological behaviors have also been proposed (reproduction, meeting, brooding, nursery, storage). Gaillard and Olivero (2009) also proposed farming behaviour for the similar burrow Halimedides. According to Myint (2009), the swollen chambers of Type II of Psilonichnus quetis might have played different roles than turn-arounds. They are interpreted as: pauses during the process of burrowing, shelter for the trace-maker, space utilization (in some cases for breeding) and the position of greatest stability against collapse. Gaillard and Olivero (2009) suggested that the configuration of the chambers along the tunnel in Halimedides was organized for the ventilation of the burrow system. These authors, as well as Lukeneder et al. (2012), connected the densely and sparsely 
chambered burrows with various oxygenation levels of the sea floor and the character of the substrate (stiffground to firmground).

Among contemporary macrofaunal burrows, Koo and Koh (2013) described a burrow of the polychaete Periserrula leucophryna, which consists of a main vertical, unbranched shaft with several bulges (diameter up to $10 \mathrm{~cm}$ ) for turn-around. Despite its general similarity to Rosarichnoides, this type of burrow has distinct characteristics. Its shaft is slightly sinuous, the constrictions are much longer and bulges have an irregular/oval shape and a thin short "peduncule". For these reasons such a tracemaker (a polychaete) could not produce Rosarichnoides.

Ichnogenus Thalassinoides Ehrenberg, 1944

Thalassinoides paradoxicus (Woodward, 1830)

$$
\text { (Fig. 8A) }
$$

1967 Thalassinoides paradoxica (Woodward), Kennedy, p. 142-148, pl. 3, pl. 4, pl. 8, fig. 5, pl. 9, fig. 2, text-figs 4, 5A, B. 2011 Thalassinoides paradoxicus (Woodward), Tiwari et al., $p$. 1139, pl. 4e.

M a te rial. - One specimen found in the Żerkowice Quarry, Coniacian, North Sudetic Synclinorium.

Diagnosis. - "Sparsely to densely but irregularly branched, subcylindrical to cylindrical burrows oriented at various angles with respect to bedding; T-shaped intersections are more common than Y-shaped bifurcations, and offshoots are not necessarily the same diameter as the parent trunk" (after Howard and Frey, 1984: 213).

D e s c r i p t i o n. - The specimen studied is a horizontal, irregularly branched, cylindrical and unlined burrow with a Trather than $Y$-shaped branching pattern. It has variable diameter $(1.0-3.0 \mathrm{~cm})$ and rare swellings. The visible length is $25 \mathrm{~cm}$. At the end of the burrow, Y-shape branching appears. Two T-shaped branchings are also observed (Fig. 8A). The burrow fill is the same as the host rock. The irregular pattern of branching and variable diameter allows it to be assigned to Thalassinoides paradoxicus.

Remarks. - Thalassinoides is interpreted as a fodinichnion (Bromley, 1996), domichnion (Myrow, 1995) and occasionally agrichnion (Ekdale and Bromley, 2003). According to Buatois et al. (2016), Thalassinoides is regarded mostly as fodinichnion. Thalassinid shrimps, ghost shrimps, lobsters, crayfish, crabs as well as fish, anemones and enteropneusts are mainly suggested as the potential tracemakers (Frey et al., 1984; Myrow, 1995; Kim et al., 2002; Ekdale and Bromley, 2003; Neto de Carvalho et al., 2007).

This eurybathic ichnotaxon may occur in the Psilonichnus, Cruziana, and even in the Teredolites ichnofacies (MacEachern et al., 2007, 2012). It appears also in the Nereites and Zoophycos ichnofacies. It may characterize firmgrounds (Glossifungites ichnofacies) and hardgrounds (Trypanites ichnofacies; Myrow, 1995).

This ichnogenus occurs in different marine environments, more commonly in shallow marine settings (Ekdale and Bromley, 2003; Rodríguez-Tovar and Uchman, 2004a, b, 2010; Malpas et al., 2005). In siliciclastic storm deposits, Thalassinoides is abundant from the distal lower shoreface to offshore settings (Pemberton et al., 2012). Thalassinoides is known from the Cambrian to the Recent (Myrow, 1995; Sprechmann et al., 2004; Mángano and Buatois, 2016), but is most abundant in the Mesozoic and the Cenozoic (Rodríguez-Tovar and Uchman, 2004a, b).

\section{DESCRIPTION OF THE ASSOCIATED FOSSILS}

\author{
Type: Mollusca \\ Class: Bivalvia \\ Order: Praecardioida \\ Family: Inoceramidae Zittel, 1881 \\ Genus: Inoceramus Sowerby, 1814 \\ Inoceramus kleini Müller, 1888
}

(Fig. 8C)

19121-3 Inoceramus Kleini Müll. var - Scupin, p. 209, Taf. 11, fig. $4 a, b$.

1934 Inoceramus kleini Müller - Andert, p. 115-117, Taf. 4, figs. 9-11, Taf. 5, figs. 1-2.

1960 Inoceramus kleini Müller - Radwańska, tab. 1, fig. f.

1991 Inoceramus kleini Müller - Tarkowski, p. 109-110, tabl. 13, fig. 7 ; tabl. 14, figs. $2,3$.

1996 Inoceramus kleini Müller - Walaszczyk, p. 386, fig. 8E.

$\mathrm{M}$ a t e $\mathrm{r}$ i a I. - One external imprint of a right valve found in the Czaple Quarry A (Fig. 1B).

$\mathrm{D}$ e s c r i p t i o n. - The valve is very convex, small, with a strong and sharp beak. Axial length is $7 \mathrm{~cm}$. Secondary axis is $\sim 5.5 \mathrm{~cm}$. Ventral margin is gently rounded. Hinge line is partially visible. Ornamentation of the valve consists of concentric and regular rugae. The ribs are $0.5-0.8 \mathrm{~cm}$ apart. The specimen does not differ from similar specimens described by Scupin (1912-1913), Radwańska (1960), Tarkowski (1991) and Walaszczyk (1996).

O c c u r r e n c e. - Scupin (1912-13) described this species from the upper Coniacian of the North Sudetic Synclinorium (Gaszów, formerly Gehnsdorf). Radwańska (1960) cited this taxon from the Coniacian of the Upper Nysa Kłodzka Graben. According to Tarkowski (1991), this species occurs in the lower Coniacian of East Europe, the middle Coniacian of the Opole Trough, the Coniacian of Germany and Poland. Walaszczyk (1996) described I. kleini from the lower middle Coniacian of Saxony and Bohemia. Walaszczyk et al. (2004) cited early forms of Inoceramus kleini, from the upper lower and lower middle Coniacian of the Euramerican biogeographic region.

\section{Inoceramus sp.}

(Fig. 8B)

M a t e ri a I. - One specimen of a left valve, the Czaple Quarry A (Fig. 1B).

D e s c ription. - Large, convex valve, with a strong beak. Axial length is $20 \mathrm{~cm}$. Secondary axis is $\sim 14 \mathrm{~cm}$. Ventral margin is gently rounded. Hinge line is partially visible. Ornamentation of the valve consists of concentric, regular rugae (up to $1.5 \mathrm{~cm}$ spacing), which are poorly visible due to the state of preservation.

$\mathrm{R}$ e $\mathrm{m}$ a r k s. - The specimen is very similar to Scupin's form (1912-13: Taf. 9, fig. 14) of the upper Coniacian of Czaple (former Hockenau). The author described large inoceramids, which are 18-24 cm long as Inoceramus nov. spec. (ex. aff. 

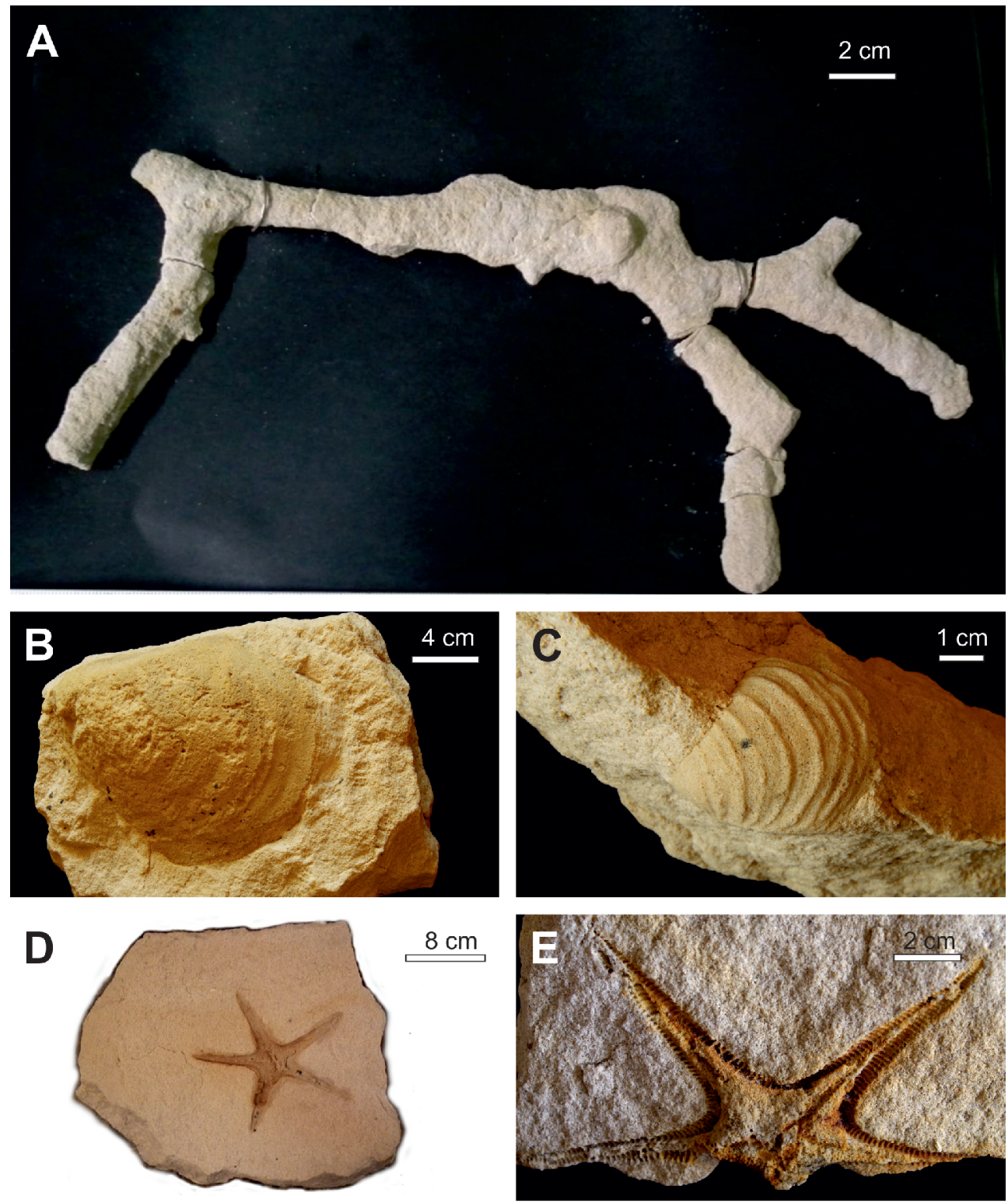

Fig. 8. Associated trace and body fossils

A - Thalassinoides paradoxicus (Woodward, 1830), Żerkowice Quarry; B - Inoceramus sp., Czaple Quarry A; C - Inoceramus kleini Müller, 1888, Czaple Quarry A; D, E - Astropecten scupini Andert, 1934, Czaple Quarry B (the same specimen, positive and negative)

cycloidis Wegner). The poor state of preservation of our specimen does not allow determination at the species level.

Types: Echinodermata

Class: Asteroidea

Order: Paxillosida

Family: Astropectinidae Gray, 1840

Genus: Astropecten Gray, 1840

Astropecten scupini Andert, 1934

(Fig. 8D, E)

19121-3 Astropecten nov.spec. - Scupin, p. 256, Taf. 15, fig. 5. 1934 Astropecten scupini n. sp. - Andert, p. 71, Taf. 19, fig. 24.

Material. - One imprint of the oral part of the endoskeleton found in the Czaple Quarry B (Fig. 1B).
De s cription a n d re marks. - Pentagonal form with well-preserved marginal spines. Its arms are elongate and pointed. The diameter is $16 \mathrm{~cm}$ and the length of the arm from the centre is $\sim 8 \mathrm{~cm}$. The ambulacral groove is only partially preserved. Mouth is not visible.

O c c u r r e n c e. - Scupin (1912-13) described this species from the upper Coniacian of Czaple (Hockenau) of the North Sudetic Synclinorium. Andert (1934) cited this taxon from the upper Turonian of Saxony and Sudetes, and Soukup (1938) from the upper Turonian of Jičin (Czech Republic).

\section{PALAEOENVIRONMENT}

In the Coniacian sandstone of the Żerkowice Member (Czaple and Żerkowice quarries), a poor assemblage of fossils and trace fossils was found. Among them the interesting crustacean burrows Rosarichnoides sudeticus igen. et isp. nov. and 
Thalassinoides paradoxicus (Woodward, 1830) are present. A very well-preserved starfish Astropecten scupini Andert, 1934 and some inoceramids I. kleini Müller, 1888 and Inoceramus sp. were also found.

The most probable tracemakers of the new ichnogenus Rosarichnoides belong to decapod crustaceans (shrimps or true crabs), which are important elements of marine as well as brackish and freshwater environments (Dworschak, 2000; Hyžný et al., 2015). Dworschak (2000) cited the worldwide distribution of recent axiidean and gebiidean mud shrimps in all oceans from temperate, tropical and subtropical latitudes $\left(60^{\circ}\right.$ north and south). According to Dworschak (2000, 2005), 95\% of known callianassid crustacean species inhabit shallow-water (0-200 m) environments. Most of the fossil ghost shrimps have been reported from shallow-water deposits and they are the most important bioturbators (see Hyžný and Klompmaker, 2015). Burrowing crabs are typical of intertidal areas (upper-intertidal zone) and they do not build their burrows below the fair-weather wave-base (see Hyžný et al., 2015 and references therein)

Thalassinoides is a common trace fossil in the Cruziana ichnofacies. It characterizes mainly the proximal Cruziana ichnofacies (see ichnological-sedimentological model of Pemberton et al., 2001, 2012), which is located in the distal lower shoreface. The occurrence of Thalassinoides in such an environment (distal lower shoreface/upper offshore) was reported by several authors (e.g., Uchman and Krenmayr, 2004; Pervesler et al., 2011; Angulo and Buatois, 2012). Individual occurrences of this ichnogenus may be found in shallower settings such as the upper and middle shoreface (Leszczyński, 2010; Buatois and Mángano, 2011; Mayoral et al., 2013). Thalassinoides is an indicator of a well-oxygenated environment (Buatois and Mángano, 2011) and its most probable producers (shrimps) prefer shallow water of normal salinity (Weimer and Hoyt, 1964; Frey et al., 1978).

In the Sudetes, Thalassinoides has been described from the Carboniferous by Muszer and Uglik (2013), from the Middle Triassic, Lower Muschelkalk (Chrząstek, 2013a) and from the Upper Cretaceous (Rotnicka, 2005; Leszczyński, 2010; Chrząstek, 2013b, c; Chrząstek and Sołczerski, 2016). Rotnicka (2005) cited this ichnogenus from the Cenomanian and Turonian of the Stołowe Mountains (Intra-Sudetic Synclinorium) from offshore/shelf settings. Leszczyński (2010) recorded this ichnogenus from the Żerkowice Member (Rakowice Małe, Coniacian), from foreshore to upper shoreface deposits, and from the Nowogrodziec Member (Rakowice Małe, Santonian) from a coastal plain setting. Chrząstek (2013b, c) and Chrząstek and Sołczerski (2016) described this ichnogenus from the middle Turonian and Coniacian of the Upper Nysa Kłodzka Graben (Bystrzyca, Długopole, Idzików, Stary Waliszów) from lower shoreface to upper offshore deposits.

Inoceramids (Inoceramus kleini and Inoceramus sp.), as found in the Coniacian sandstones, are very common and cosmopolitan in Mesozoic marine shelf environments (see Ozanne and Harries, 2002; Kumagae et al., 2011; Chrząstek, 2012). As eurytopic organisms they had broad ecological tolerances and are known from well-oxygenated, shallow marine to poorly oxygenated, deep-marine settings (Harries and Ozanne 1998; Ozanne and Harries, 2002).

The presence of the starfish Astropecten scupini also suggests shallow marine settings. Astropectenids used to occur in abundance down to a water depth of $50 \mathrm{~m}$ (Beddingfield and McClintock, 1993). According to Villier et al. (2004), astropectenids are found predominantly in shallow shelf environments (shoreface). These starfish are well-adapted to soft-bottom substrates, being detritivores and predators of gas- tropods, bivalves and crustaceans (Caregnato et al., 2009; Blake and Guensburg, 2016). According to these authors, starfish (including astropectenids) live in up to $30 \mathrm{~m}$ water depth, in some cases up to $\sim 80 \mathrm{~m}$. However, Baeta et al. (2016) reported Astropecten from the nearshore to offshore $(5-150 \mathrm{~m})$ with small individuals prevailing in the nearshore $(5-50 \mathrm{~m})$, and larger forms in the deeper areas $(50-150 \mathrm{~m})$. The presence of the starfish Astropecten scupini suggests a shoreface setting.

Leszczyński (2010) interpreted the Coniacian sandstones of the Żerkowice Member as bar and storm deposits, which were deposited mainly in the foreshore to upper shoreface setting. This is supported by opposite directions of large-scale cross-stratification, which indicate significant variations in wave/current direction and occasionally energetic hydrodynamic conditions. However, Leszczyński (2010), who studied the deposits of the Rakowice Quarry, stated that in the adjacent quarry at Żerkowice a more diverse assemblage of trace fossils occurs, in which horizontal burrows Ophiomorpha and Thalassinoides prevail. This suggests short calmer periods and periodic conditions characteristic of the distal expression of the Skolithos ichnofacies (Leszczyński, 2010), located in the middle shoreface setting.

Our studies are in agreement with the sedimentological analysis of Leszczyński (2010). In the Czaple quarries we observed fine-grained, well-sorted quartz sandstones with the same sedimentary structures as Leszczyński (2010) described, which are represented by planar stratification, ripple marks and large-scale cross-stratification. In most cases the sandstones are structureless. HCS (hummocky cross-stratification) was not found. In our opinion, sedimentation took placed above the fair-weather wave base, in a moderate to high energy environment with some calmer episodes.

The assemblage of trace and body fossils studied is of low diversity. As Leszczyński (2010) stated, "the rarity of trace fossils in the Żerkowice Member may result from low stability of the sandy substrate caused by high water energy and deficiency of food in the depositional environment". The presence of the trace fossils studied (Rosarichnoides sudeticus, Thalassinoides paradoxicus) and body fossils (starfish Astropecten scupini, inoceramids: Inoceramus kleini, Inoceramus sp.) suggests deposition of the Coniacian sandstones in a shallow-marine environment, probably upper part of the shoreface. Recently, Chrząstek and Wypych (2016) reported a more diverse trace fossil assemblage from the Coniacian sandstones of the Czaple-Nowa Wieś Grodziska quarries, comprising Planolites, Phycodes, Gyrochorte, Ophiomorpha and Thalassinoides that together point to shoreface environments. On the basis of previous sedimentological and ichnological studies (Leszczyński, 2010; Chrząstek and Wypych, 2016) as well as our studies, it can be concluded that the sedimentation of the Żerkowice Member sandstones is typical of a soft-bottom, well-oxygenated and normal salinity shallow marine environment, above the fair-weather wave base (up to the middle shoreface).

\section{CONCLUSIONS}

The unique trace fossil described as Rosarichnoides sudeticus igen. et isp. nov. has been found in the Coniacian sandstones of the North Sudetic Synclinorium (Rakowice Wielkie Formation, Żerkowice Member, Czaple Quarry B). Rosarichnoides is interpreted as a characteristic rosary-shaped, unbranched and unwalled burrow, which consists of alternating asymmetrical oval to pear-shaped chambers (swellings) and constrictions. Its fill is passive and structureless, 
similar to the host sediment. The surface of the burrow is rough rather than smooth, but some ridges and sand knobs or furrows may occur. This new ichnogenus is distinguished from other ichnotaxa by a lack of branching, and the different orientation and shape of swellings. It may be considered a representative of an "ophiomorphid" group. Based on burrow morphology the tracemaker of Rosarichnoides may have been a deposit or detritus feeder among decapod crustaceans (most probably a shrimp or crab). Additionally, Thalassinoides paradoxicus (Woodward, 1830) as well as the starfish Astropecten scupini Andert, 1934, inoceramids Inoceramus kleini Müller, 1888, Inoceramus sp. have also been encountered.

The trace fossil assemblage and macrofossils support the palaeoenvironmental interpretation of the the Żerkowice Member by Leszczyński (2010). The Coniacian sandstones studied were probably deposited in the foreshore to middle shoreface (archetypal Skolithos ichnofacies). Sedimentation took place in a shallow epicontinental sea, above the fair-weather wave base. Waters were well-oxygenated (Thalassinoides) and of normal salinity (shrimps, starfish). The sedimentation of the sandstones studied was related to the regression that started after uplift of the southeastern part of the North Sudetic Basin.

Acknowledgements. All specimens studied were made available by courtesy of the Kamieniarz Czaple Company. The authors thank very much $A$. Uchman for insights which were very helpful to recognize the study specimen. We wish to thank V. Šimo for helpful remarks and M. Myint and D. Olivero for publications. We are also grateful to K. Pluta for some photographs of the specimens studied. Thanks are also given to the reviewers D. Knaust, C. Neto de Carvalho and A. Uchman for their helpful remarks. This research was financed by the grants ING UWr 0401/1017/16.

\section{REFERENCES}

Alberti, F., 1834. Beitrag zu einer Monographie des bunten Sandsteins, Muschelkalks und Keupers, und die Verbindungdieser. Verlag Cotta, Stuttgart u. Tübingen, I-XX: 1-366.

Andert, H., 1934. Die Kreideablagerungen zwischen Elbe und Jeschken. Teil 3: Die Fauna der obersten Kreide in Sachsen, Böhmen und Schlesien. 159: 1-477.

Angulo, S., Buatois, L.A., 2012. Ichnology of a Late Devonian-Early Carboniferous low-energy seaway: the Bakken Formation of subsurface Saskatchewan, Canada: assessing paleoenvironmental controls and biotic responses. Palaeogeography, Palaeoclimatology, Palaeoecology, 315-316: 46-60.

Baeta, M., Galimany, E., Ramón, M., 2016. Growth and reproductive biology of the sea star Astropecten aranciacus (Echinodermata, Asteroidea) on the continental shelf of the Catalan Sea (northwestern Mediterranean). Helgoland Marine Research, 70: 1-22.

Baranowski, Z., Haydukiewicz, A., Kryza, R., Lorenc, S., Muszyński, A., Solecki, A., Urbanek, Z., 1990. Outline of the geology of the Góry Kaczawskie (Sudetes, Poland). Neues Jahrbuch für Geologie und Paläontologie Abhandlungen, 179: 223-257.

Beddingfield, S.D., McClintock, J.B., 1993. Feeding behavior of the sea star Astropecten articulatus (Echinodermata: Asteroidea): an evaluation of energy-efficient foraging in a soft-bottom predator. Marine Biology, 115: 669-676.

Belaústegui, Z., Gibert, J.M. de, López-Blanco, M., Bajo, I., 2014. Recurrent constructional pattern of the crustacean burrow Sinusichnus sinuosus from the Paleogene and Neogene of Spain. Acta Palaeontologica Polonica, 59: 461-474.

Belaústegui, Z., Muńiz, F., Mángano, M.G., Buatois, L.A., Domčnech, R., Martinell, J., 2016. Lepeichnus giberti igen. nov. isp. nov. from the upper Miocene of Lepe (Huelva, SW Spain): evidence for its origin and development with proposal of a new concept, ichnogeny. Palaeogeography, Palaeoclimatology, Palaeoecology, 452: 80-89.

Beyer, K., 1933. Das Liegende der Kreide in den Nordsudeten. Neues Jahrbuch für Mineralogie, Beilage-Band, B 69: 450-508.

Beyer, K., 1934. Zur kimmerischen Faltung in den Nordsudeten. Zeitschrift der Deutschen Geologischen Gesellschaft, 86: 702-702.

Beyrich, E., 1849. Das Quadersandsteingebirge in Schlesien. Zeitschrift der Deutschen Geologischen Gesellschaft, 1: 390-393.

Beyrich, E., 1855. Ueber die Lagerung der Kreideformation im schlesischen Gebirge. Abhandlungen der Königlichen Akademie der Wissenschaften zu Berlin, 26: 57-80.
Biernacka, J., 2012. Provenance of Upper Cretaceous quartz-rich sandstones from the North Sudetic Synclinorium, SW Poland: constraints from detrital tourmaline. Geological Quarterly, 56 (2): 315-332.

Blake, D.B., Guensburg, T.E., 2016. An asteroid (Echinodermata) faunule from the Oxfordian Swift Formation (Upper Jurassic) of Montana. Journal of Paleontology, 90: 1160-1168.

Bromley, R.G., 1996. Trace Fossils. Biology, Taphonomy and Applications. Chapman and Hall, London.

Bromley, R.G., Frey, R.W., 1974. Redescription of the trace fossil Gyrolithes and taxonomic evaluation of Thalassinoides, Ophiomorpha and Spongeliomorpha. Bulletin of the Geological Society of Denmark, 23: 311-335.

Buatois, L.A., Mángano, M.G., 2011. Ichnology: Organism-Substrate Interactions in Space and Time. Cambridge University Press.

Buatois, L.A., Carmona, N.B., Curran, H.A., Netto, R.G., Mángano, M.G., Wetzel, A., 2016. The Mesozoic marine revolution. In: The Trace-Fossil Record of Major Evolutionary Events, 2: Mesozoic and Cenozoic (eds. M.G. Mángano and L.A. Buatois): 19-134. Springer, Heidelberg.

Caregnato, F.F., Wiggers, F., Tarasconi, J.C., Veitenheimer-Mendes, I.L., 2009. Taxonomic composition of mollusks collected from the stomach content of Astropecten brasiliensis (Echinodermata: Asteroidea) in Santa Catarina, Brazil. Revista Brasileira de Biocięncias, 7: 252-259.

Chamberlain, C.K., Baer, J.L., 1973. Ophiomorpha and a new thalassinid burrow from the Permian of Utah. Brigham Young University, Geology Studies, 20: 79-94.

Chrzastek, A., 2002. Stratigraphy and sedimentation conditions of Roet and Lower Muschelkalk of the North Sudetic Basin (in Polish with English summary). Acta Universitatis Wratislaviensis 2383, Prace Geologiczno-Mineralogiczne, 73: 1-128.

Chrząstek, A., 2012. Palaeontology of the Middle Turonian limestones of the Nysa Kłodzka Graben (Sudetes, SW Poland): biostratigraphical and palaeogeograpical implications. Geologos, 18: 83-109.

Chrząstek, A., 2013a. Trace fossils from the Lower Muschelkalk of Raciborowice Górne (North Sudetic Synclinorium, SW Poland) and their palaeoenvironmental interpretation. Acta Geologica Polonica, 63: 315-353.

Chrząstek, A., 2013b. Middle Turonian trace fossils from the Bystrzyca and Długopole sandstones in the Nysa Kłodzka Graben (Sudetes, SW Poland). Geological Quarterly, 57 (3): 443-466.

Chrząstek, A., 2013c. Rekonstrukcja paleośrodowiska górnokredowych zlepieńców idzikowskich na podstawie 
skamieniałości śladowych (rów Nysy Kłodzkiej, Idzików) (in Polish). In: Aktualizm i antyaktualizm w paleontologii (eds. M. Kędzierski and B. Kołodziej), XXII Konferencja Naukowa Sekcji Paleontologicznej PTG, Tyniec 27-30.IX.2013: 10-11.

Chrząstek, A., Sołczerski, R., 2016. Crustacean burrows from the Lower Idzików Beds (Stary Waliszów, Upper Nysa Kłodzka Graben) (In Polish). In: XXIII Konferencja Naukowa Sekcji Paleontologicznej Polskiego Towarzystwa Geologicznego, abstrakty (eds. K. Pawłowska and D. Pawłowski), Poznań 21-23.09.16: 25-26.

Chrzastek, A., Wypych, M., 2016. Trace fossils from the quartz sandstones (Coniacian) from the North Sudetic Synclinorium (Czaple) (in Polish). In: XXIII Konferencja Naukowa Sekcji Paleontologicznej PTG, abstrakty (eds. K. Pawłowska and D. Pawłowski), 21-23.09.2016, Poznań: 27-28.

D'Alessandro, A., Bromley, R.G., 1995. A new ichnospecies of Spongeliomorpha from the Pleistocene of Sicily. Journal of Paleontology, 69: 393-398.

Dettmer, F., 1912. Spongites saxonicus Geinitz und die Fucoidenfrage. Neues Jahrbuch für Mineralogie, Geologie und Paläontologie, 1912 (2): 114-126, http://kreidefossilien.de/1724

Dettmer, F., 1915. Neues zum Fucoidenproblem. Centralblatt für Mineralogie, Geologie und Paläontologie, 285-287.

Dunker, W., 1856. Ueber mehre Pflanzenreste aus dem Quadersandsteine von Blankenburg, 4: 179-183.

Dworschak, P.C., 2000. Global diversity in the Thalassinidea (Decapoda). Journal of Crustacean Biology, 20: 238-245.

Dworschak, P.C., 2001. The burrows of Calianassa tyrrhena (Petagna 1792) (Decapoda: Thalassinidea). Marine Ecology, 22: $155-166$

Dworschak, P.C., 2005. Global diversity in the Thallassinidea (Decapoda): an update (1998-2004). Nauplius, 13: 57-63.

Dworschak, P.C., Ott, J.A., 1993. Decapod burrows in mangrove-channel and back-reef environments at the Atlantic Barrier Reef, Belize. Ichnos, 2: 277-290.

Ehrenberg, K., 1944. Ergänzende Bemerkungen zu den seinerzeit aus dem Miozän von Burgschleinitz beschrieben Gangkernen und Bauten dekapoder Krebse. Paläontologische Zeitschrift, 23: 354-359.

Ekdale, A.A., Bromley, R.G., 2003. Paleoethologic interpretation of complex Thalassinoides in shallow-marine limestones, Lower Ordovician, southern Sweden. Palaeogeography, Palaeoclimatology, Palaeoecology, 192: 221-227.

Frey, R.W., Curran, H.A., Pemberton, S.G., 1984. Tracemaking activities of crabs and their environmental significance: the ichnogenus Psilonichnus. Journal of Paleontology, 58: 333-350.

Frey, R.W., Howard, J.D., Pryor, W.A., 1978. Ophiomorpha: its morphologic, taxonomic and environmental significance. Palaeogeography, Palaeoclimatology, Palaeoecology, 23: 199-229.

Frič, A., 1883. Studien im Gebiete der Böhmischen Kreideformation. Palaeontologische Untersuchungen der einzelnen Schichten. III. Die Iserschichten. Mit 132 Textfiguren. Archiv für die naturwissenschaftliche Landesdurchforschung von Böhmen (Commissions-Verlag Fr. Rivnác), Prague, 5, http://kreidefossilien.de/299

Fürsich, F.T., 1973. A revision of the trace fossils Spongeliomorpha, Ophiomorpha and Thalassinoides. Neues Jahrbuch für Geologie und Paläontologie, Monatshefte: 719-735.

Gaillard, C., Olivero, D., 2009. The ichnofossil Halimedides in Cretaceous pelagic deposits from the Alps: environmental and ethological significance. Palaios, 24: 257-270.

Geinitz, H.B., 1842. Die sächsisch-böhmische Schweiz, die Oberlausitz und das Innere von Böhmen. In: Charakteristik der Schichten und Petrefacten des sächsisch-böhmischen Kreidegebirges (ed. H.B. Geinitz): 63-116. Dresden und Leipzig in der Arnoldischen Buchandlung.

Gibert, J.M. de, 1996. A new decapod burrow system from the NW Mediterranean Pliocene. Revista Española de Paleontología, 11: $251-254$.
Gibert, J.M. de, Ekdale, A.A., 2010. Paleobiology of the crustacean trace fossil Spongeliomorpha iberica in the Miocene of southeastern Spain. Acta Palaeontologica Polonica, 55: 733-740.

Göhler, T., 2011a. Eine komplizierte Gangetage im Grabgangsystem Thalassinoides saxonicus (Geinitz) aus dem tidal beeinflussten unteren Ober-Cenomanium des Tharandter Waldes. Beiträge zur Geologie der Sächsischen Kreide, 7-9: 49-58.

Göhler, T., 2011b. Betrachtungen einiger Grabgangstücke [u.a. Ophiomorpha nodosa Lundgren und Thalassinoides saxonicus (Geinitz)] aus obercenomanen Sandsteinen des Tharandter Waldes. Beiträge zur Geologie der Sächsischen Kreide, 7-9: 59-64.

Göppert, J.H.R., 1842. Über die fossile Flora der Quadersandsteinformation in Schlesien - als erster Beitrag zur Flora der Tertiärgebilde. Novorum Actorum Academiae Caesareae Leopoldino-Carolinae Naturae Curiosum [=Verhandlungen der kaiserlichen leopoldinisch-carolinischen Akademie der Naturforscher] (Eduard Weber) Breslau und Bonn, 19: 99-134, http://kreidefossilien.de/1726

Göppert, J.H.R., 1847. Zur Flora des Quader-Sandsteins in Schlesien, als Nachtrag zu der früher erschienen Abhandlung über den selben Gegenstand. Novorum Actorum Academiae Caesareae Leopoldino-Carolinae Naturae Curiosum [=Verhandlungen der kaiserlichen leopoldinisch-carolinischen Akademie der Naturforscher] (Eduard Weber) Breslau und Bonn 14: 353-365, http:// kreidefossilien.de/1727

Gray, J.E., 1840. A synopsis of the genera and species of the class Hypostoma Asterias (Linn.). Annals and Magazine of Natural History, 6: 275-290.

Griffis, R.B., Suchanek, T.H., 1991. A model of burrow architecture and trophic modes in thalassinidean shrimp (Decapoda: Thalassinidea). Marine Ecology Progress Series, 79: 171-183.

Häntzschel, W., 1962. Part W. Miscellanea. Trace Fossils and Problematica. In: Treatise on Invertebrate Paleontology (ed. R.C. Moore). Geological Society of America and University of Kansas Press.

Häntzschel, W., 1975. Part W. Miscellanea. Supplement 1. Trace Fossils and Problematica. In: Treatise on Invertebrate Paleontology (ed. C. Teichert). Geological Society of America and University of Kansas, Lawrence and Boulder.

Harries, P.J., Ozanne, C.R., 1998. General trends in predation and parasitism upon inoceramids. Acta Geologica Polonica, 48: 377-386.

Holdefleiss, G., 1915. Das Triasvorkommen von Gross-Hartmannsdorf in Niederschlesien. Jahresbericht der Schlesischen Gesellschaft für vaterländische Kultur, 92: 1-23.

Howard, J.D., Frey, R.W., 1984. Characteristic trace fossils in nearshore to offshore sequences, Upper Cretaceous of east-central Utah. Canadian Journal of Earth Sciences, 21: 200-219.

Hyžný, M., 2011. In situ mud shrimps (Decapoda: Axiidea: Callianassidae) preserved within their burrows from the middle Miocene of the Central Paratethys. Bulletin of the Mizunami Fossil Museum, 37: 37-46.

Hyžný, M., Klompmaker, A.A., 2015. Systematics, phylogeny, and taphonomy of ghost shrimps (Decapoda): a perspective from the fossil record. Arthropod Systematics \& Phylogeny, 73: 401-437.

Hyžný, M., Šimo, V., Starek, D., 2015. Ghost shrimps (Decapoda: Axiidea: Callianassidae) as producers of an Upper Miocene trace fossil association from sublittoral deposits of Lake Pannon (Vienna Basin, Slovakia). Palaeogeography, Palaeoclimatology, Palaeoecology, 425: 50-66.

Kennedy, W.J., 1967. Burrows and surface traces from the Lower Chalk of southern England. Bulletin of the British Museum (Natural History) Geology London, 15: 125-167.

Kim, J.-Y., Kim, K.-S., Pickerill, R.K., 2002. Cretaceous nonmarine trace fossils from the Hasandong and Jinju Formations of the Namhae Area, Kyongsangnamdo, southeast Korea. Ichnos, 9: 41-60. 
Kollmann, H.A., 2002. Gastropods from the Lower Cretaceous of Vorarlberg, Austria. A systematic review. Annalen des Naturhistorischen Museums in Wien, 103A: 23-73.

Koo, B.J., Koh, C.-H., 2013. Oxygen penetration through Invertebrate burrow walls in Korean tidal flat. Ocean Science Journal, 48: $329-338$

Kumagae, T., Maeda, H., Komatsu, T., 2011. Paleoecology of Inoceramus amakusensis Nagao et Matsumoto, 1940 (Bivalvia) in a Late Cretaceous shallow clastic sea: the Himenoura Group, Kyushu, Japan. Cretaceous Research, 32: 738-749.

Kützing, F.T., 1841. Über die "Polypieres calciféres" des Lamouroux. In: Zu der öffentlichen Prüfung sämmtlicher Classen der Realschule zu Nordhausen 1841 (ed. F.T. Kützing): 3-34. Realschule, Nordhausen.

Lepper, J., Rambow, D., Röhling, H.-G., 2002. Der Buntsandstein in der Stratigraphischen Tabelle von Deutschland. Newsletters on Stratigraphy, 41: 129-142.

Leszczyński, S., 2010. Coniacian-?Santonian paralic sedimentation in the Rakowice Małe area of the North Sudetic Basin, SW Poland: sedimentary facies, ichnological record and palaeogeographical reconstruction of an evolving marine embayment. Annales Societatis Geologorum Poloniae, 80: 1-24.

Lewy, Z., Goldring, R., 2006. Campanian crustacean burrow system from Israel with brood and nursery chambers representing communal organization. Palaeontology, 49: 133-140.

Lorenz von Liburnau, J.R., 1902. Ergänzung zur Beschreibung der fossilen Halimeda fuggeri: Sitzungsberichte der kaiserlich-königlichen Akademie der Wissenschaften, Mathematisch-Naturwissenschaftliche Klasse, 111: 685-712.

Lukeneder, A., Uchman, A., Gaillard, C., Olivero, D., 2012. The late Barremian Halimedides horizon of the Dolomites (Southern Alps, Italy). Cretaceous Research, 35: 199-207.

Lundgren, B., 1891. Studier öfver fossilförande lösa block. Geologiska Föreningen i Stockholm Förhandlinger, 13: 111-121.

MacEachern, J.A., Pemberton, S.G., Gingras, M.K., Bann, K.L., 2007. The ichnofacies paradigm: a fifty-year retrospective. In: Trace Fossils. Concepts, Problems, Prospects (ed. W. Miller III): 52-77. Elsevier.

MacEachern, J.A., Bann, K.L., Gingras, M.K., Zonneveld, J.-P., Dashtgard, S.E., Pemberton, S.G., 2012. The ichnofacies paradigm. Developments in Sedimentology, 64: 103-138.

Malpas, J.A., Gawthorpe, R.L., Pollard, J.E., Sharp, I.R., 2005. Ichnofabric analysis of the shallow marine Nukhul Formation (Miocene), Suez Rift, Egypt; implications for depositional processes and sequence stratigraphic evolution. Palaeogeography, Palaeoclimatology, Palaeoecology, 215: 239-264.

Mángano, M.G., Buatois, L.A., 2016. The Cambrian Explosion. Topics in Geobiology, 39: 73-126.

Mayoral, E., Ledesma-Vazgues, J., Baarli, B.G., Santos, A., Ramalho, R., Cachăo, M., Silva, C.M. da, Johnson, M.E., 2013. Ichnology in oceanic islands; case studies from the Cape Verde Archipelago. Palaeogeography, Palaeoclimatology, Palaeoecology, 381-382: 47-66.

Menning, M., Deutsche Stratigraphische Kommission, 2012. Erlauterung zur Stratigraphischen Tabelle von Deutschland Kompakt 2012. [Explanatory notes to the Stratigraphic Table of Germany Compact 2012.]. Zeitschrift der Deutschen Gesellschaft für Geowissenschaften, 163: 385-409.

Milewicz, J., 1956. Zaburzenie utworów kredowych w Rakowicach Małych (in Polish). Przegląd Geologiczny, 4: 361-364.

Milewicz, J., 1965. Facies of the Upper Cretaceous in the eastern part of the North Sudetic Basin (in Polish with English summary). Biuletyn Instytutu Geologicznego, 170: 15-80.

Milewicz, J., 1979. Distribution of Cretaceous rocks in the North-Sudetic Basin (in Polish with English summary). Kwartalnik Geologiczny, 23 (4): 819-826.

Milewicz, J., 1985. A proposal of formal stratigraphic subdivision of the infill of the North Sudetic Depression (in Polish with English summary). Przegląd Geologiczny, 33: 385-390.

Milewicz, J., 1997. Upper Cretaceous of the North-Sudetic depression (litho-and biostratigraphy, paleogeography, tectonics and remarks on raw material (in Polish with English summary). Acta Universitatis Wratislaviensis, Prace Geologiczno-Mineralogiczne, 59: 5-58.

Morris, J., Lycett, J., 2015. A monograph of the Mollusca from the Great Oolite. Cambridge Library Collection, 1, Chiefly from Minchinhampton and the coast of Yorkshire. Cambridge University Press.

Musstow, R., 1968. Beitrag zur Stratigraphie und Paläogeographie der Oberkreide und des Albs in Ostbrandenburg und der östlichen Niederlausitz. Geologie, 17: 1-71.

Muszer, J., Uglik, M., 2013. Palaeoenvironmental reconstruction of the Upper Visean Paprotnia Beds (Bardo Unit, Polish Sudetes) using ichnological and palaeontological data. Geological Quarterly, 57 (3): 365-384.

Müller, G., 1888. Beiträge zur Kenntnis der oberen Kreideformation am nordlichen Harzrand. Jahrbuch der Preussischen Geologischen Landesanstalt und Bergacademie, 8: 372-456.

Myint, M., 2001. Psilonichnus quietis isp. nov. from the Eocene Iwaki Formation, Shiramizu Group, Joban Coal Field, Japan. Ichnos, 8: 1-14.

Myint, M., 2009. The Psilonichnus ichnofacies: an example from the Iwaki Formation, Shiramizu Group, Joban Coal Field, Japan. SEPM Special Publications, 52: 1-7.

Myrow, P.M., 1995. Thalassinoides and the enigma of Early Paleozoic open-framework burrow systems. Palaios, 10: 58-74.

Neto de Carvalho, C., Rodrigues, N.P.C., 2007. Compound Asterosoma ludwigae Schlirf, 2000 from the Jurassic of the Lusitanian Basin (Portugal): conditional strategies in the behavior of Crustacea. Journal of Iberian Geology, 33: 295-310.

Neto de Carvalho, C.N., Viegas, P.A., Cachăo, M., 2007. Thalassinoides and its producer: populations of Mecochirus buried within their burrow systems, Boca do Chapim Formation (Lower Cretaceous), Portugal. Palaios, 22: 104-109.

Netto, R.G., Buatois, L.A., Mángano, M.G., Balistieri, P., 2007. Gyrolithes as a multipurpose burrow: an ethologic approach. Revista Brasileira de Paleontologia, 10: 157-168.

Nickell, L.A., Atkinson, R.J.A., 1995. Functional morphology of burrows and trophic modes of three thalassinidean shrimp species, and a new approach to the classification of thalassinidean burrow morphology. Marine Ecology Progress Series, 128: 181-197.

Noetling, F., 1880. Die Entwickelung der Trias in Niederschlesien. Zeitschrift der Deutschen Geologischen Gesellschaft, 32: 300-349.

Otto, E., 1852. Additamente zur Flora des Quadergebirges in der Gegend um Dresden und Dippoldiswalde, enthaltend meist noch nicht oder wenig bekannte fossile Pflanzen. Dippoldiswalde, Verlag von Carl Jehne, 1-27, http://www.kreidefossilien.de/387

Ozanne, C.R., Harries, P.J., 2002. Role of predation and parasitism in the extinction of the inoceramid bivalves: an evaluation. Lethaia, 35: 1-19.

Pemberton, S.G., Spila, M., Pulham, A.J., Saunders, T., MacEachern, J.A., Robbins, D., Sinclair, I.K., 2001. Ichnology and sedimentology of shallow to marginal marine systems. Ben Nevis \& Avalon Reservoirs, Jeanne d'Arc Basin. Geological Association of Canada, Short Course Notes, 15: 1-343.

Pemberton, S.G., MacEachern, J.A., Dashtgard, S.E., Bann, K.L., Gingras, M.K., Zonneveld, J.-P., 2012. Shorefaces. Developments in Sedimentology, 64: 563-603.

Pervesler, P., Uchman, A., 2009. A new Y-shaped trace fossil attributed to upogebiid crustaceans from Early Pleistocene of Italy. Acta Palaeontologica Polonica, 54: 135-142.

Pervesler, P., Uchman, A., Hohenegger, J., Dominici, S., 2011 Ichnological record of environmental changes in Early Quaternary (Gelasian-Calabrian) marine deposits of the Stirone section, Northern Italy. Palaios, 26: 578-593.

Počta, P., 1885. Beiträge zur Kenntniss der Spongen der Böhmischen Kreideformation. III Abtheilung: Tereactinellidae, Monactinellidae, Calcispongiae, Ceratospongiae, Nachtrag. 26 Fig im Text. Abhandlungen der königlichen böhmischen 
Gesellschaft der Wissenschaften Praha, 7.1: 1-40, http://kreidefossilien.de/419

Radwańska, Z., 1960. The problem of the Upper Turonian in the Lower Silesian Cretaceous (in Polish with English summary). Kwartalnik Geologiczny, 4 (1): 113-123.

Richter, P., 1909. Beiträge zur unteren Kreide Quedlinburgs. Teil 2: Die Gattung Nathorstiana P. Richter und Cylindrites spongioides Goeppert: 1-12. Wilhelm Engelmann, Leipzig.

Rodríguez-Tovar, F.J., Uchman, A., 2004a. Ichnotaxonomic analysis of the Cretaceous/Palaeogene boundary interval in the Agost section, south-east Spain. Cretaceous Research, 25: 635-647.

Rodríguez-Tovar, F.J., Uchman, A., 2004b. Trace fossils after the K-T boundary event from the Agost section, SE Spain. Geological Magazine, 141: 429-440.

Rodríguez-Tovar, F.J., Uchman, A., 2010. Ichnofabric evidence for the lack of bottom anoxia during the Lower Toarcian Oceanic Anoxic Event in the Fuente de la Vidriera Section, Betic Cordillera, Spain. Palaios, 25: 576-587.

Rotnicka, J., 2005. Ichnofabrics of the Upper Cretaceous fine-grained rocks from the Góry Stołowe Mountains (Sudetes, SW Poland). Geological Quarterly, 49 (1): 15-30.

Saporta, G. de, 1884. Les organismes problematiques des anciennes mers. Masson, Paris.

Saporta, G. de, 1887. Nouveaux documents relatifs aux organismes problematiques des anciens mers. Bulletin de la Socičte Géologique du France, 15: 286-302.

Sawicki, L., 1967. Mapa geologiczna regionu dolnośląskiego (bez utworów czwartorzędowych) 1: 200 000. Instytut Geologiczny.

Schaffer, F.X., 1928. Hormosiroidea florentina n.g., n. sp., ein Fucus aus der Kreide der Umgebung von Florenz. Paläontologische Zeitschrift, 10: 212-215.

Schlirf, M., 2000. Upper Jurassic trace fossils from the Boulonnais (northern France). Geologica et Palaeontologica, 34: 145-213.

Schlirf, M., 2005. Revision and description of Keuper (Middle Ladinian to Rhaetian) invertebrate trace fossils from the southern part of the Germanic Basin and studies of related material. Dissertation zur Erlangung des naturwissenschaftlichen Doktorgrades der Bayerischen Julius-Maximilians-Universität, Würzburg.

Schulze, C.F., 1760. Betrachtung der versteinerten Seesterne und ihrer Theile. Warschau und Dresden (Michael Gröll). 58 p. 3 Taf., http://kreidefossilien.de/377

Scupin, H., 1907. Die stratigraphischen Beziehungen der obersten Kreideschichten in Sachsen, Schlesien und Böhmen. Neues Jahrbuch für Mineralogie, Geologie und Paläontologie, 24: 676-715.

Scupin, H., 1910. Über sudetische prätertiäre junge Krustenbewegungen und die Verteilung von Wasser und Land zur Kreidezeit in der Umgebung der Sudeten und des Erzgebirges. Zeitschrift für Naturwissenschaften, 82: 321-344.

Scupin, H., 1912-1913. Die Lowenberger Kreide und ihre Fauna. Paleontographica, Suppl. VI.

Scupin, H., 1933. Der Buntsandstein der Nordsudeten. Zeitschrift der Deutschen Geologischen Gesellschaft, 85: 161-189.

Scupin, H., 1936. Zur Paläogeographie des sudetischen Kreidemeeres. Zeitschrift der Deutschen Geologischen Gesellschaft, 88: 309-325.

Seilacher, A., 2007. Trace Fossil Analysis. Springer.

Sepahvand, V., Sari, A., Tudge, C., Bolouki, M., 2014. A study of burrow morphology in representative axiidean and gebiidean mud shrimps, from the Persian Gulf and Gulf of Oman, Iran. Nauplius, 22: 137-144

Solecki, A., 1994. Tectonics of the North Sudetic Synclinorium )n Polish with English summary). Acta Universitatis Wratislaviensis, 1618, Prace Geologiczno-Mineralogiczne, 45.

Soukup, J., 1938. Der erste Fund eines fossilen Seesternes in den Quadersandsteinen des Oberturons bei Jicin. Vierteljahrschrift für Geologie und Erdkunde der Sudetenländer, 11: 23-27.

Sowerby, J., 1814. The mineral conchology of Great Britain. London 1812-1829. Part 1
Sowerby, J. 1824 (continued by Sowerby J.) (1812-46). The mineral conchology of Great Britain. 7, London.

Sprechmann, P., Gaucher, C., Blanco, G., Montańa, J., 2004 Stromatolitic and trace fossils community of the Cerro Victoria Formation, Arroyo del Soldado Group (Lowermost Cambrian, Uruguay). Gondwana Research, 7: 753-766.

Stamhuis, E.J., Reede-Dekker, T., Etten Y van, Wiljes, J.J. de, Videler, J.J., 1996. Behaviour and time allocation of the burrowing shrimp Calianassa subterranean (Decapoda, Thalassinidea). Journal of Experimental Marine Biology and Ecology, 204: 225-239.

Tarkowski, R., 1991. Stratigraphy, macrofossils and palaeogeography of the Upper Cretaceous from the Opole Trough (in Polish with English summary). Scientific Bulletins of Stanislaw Staszic Academy of Mining and Metallurgy, 1404, Geology, 51: 1-156.

Tiwari, R.P., Rajkonwar, C., Lalchawimawii, Malsawma, P.L.J., Ralte, V.Z., Patel, S.J., 2011. Trace fossils from Bhuban Formation, Surma Group (Lower to Middle Miocene) of Mizoram India and their palaeoenvironmental significance. Journal of Earth System Science, 6: 1127-1143.

Uchman, A., 1991. "Shallow water" trace fossils in Paleogene flysch of the southern part of the Magura Nappe, Polish Outer Carpatians. Annales Societatis Geologorum Poloniae, 61: 61-75.

Uchman, A., 1995. Taxonomy and palaeoecology of flysch trace fossils: The Marnoso-arenacea Formation and associated facies (Miocene, Northern Apennines, Italy). Beringeria, 15: 3-115.

Uchman, A., 1998. Taxonomy and ethology of flysch trace fossils: Revision of the Marian Książkiewicz collection and studies of complementary material. Annales Societatis Geologorum Poloniae, 68: 105-218.

Uchman, A., Krenmayr, H.G., 2004. Trace fossils, ichnofabrics and sedimentary facies in the shallow marine Lo Miocene Molasse of Upper Austria. Jahrbuch der Geologischen Bundesanstalt, 144: 233-251.

Villier, L., Kutscher, M., Mah, C.L., 2004. Systematics and palaeoecology of middle Toarcian Asteroidea (Echinodermata) from the "Seuil du Poitou“, Western France. Geobios, 37: 807-825.

Walaszczyk, I., 1996. Inoceramids from Kreibitz-Zittauer area (Saxony and northern Bohemia): revision of Andert's (1911) descriptions. Paläontologische Zeitschrift, 70: 367-392.

Walaszczyk, I., 2008. North Sudetic Basin (Outer Sudetic Cretaceous). In: The Geology of Central Europe (ed. T. McCann), 2 (Mesozoic and Cenozoic): 959-960. The Geological Society of London, London.

Walaszczyk, I., Kopaevich, L.F., Olferiev, A.G., 2004. Inoceramid/foraminiferal succession of the Turonian and Coniacian (Upper Cretaceous) of the Briansk region (Central European Russia). Acta Geologica Polonica, 54: 569-581.

Weimer, R.J., Hoyt, J.H., 1964. Burrows of Callianassa mayor Say, geologic indicators of littoral and shallow neritic environments. Journal of Paleontology, 38: 761-767.

Wiest, L.A., Buynevich, I.V., Grandstaff, D.E., Terry Jr., D.O., Maza, Z.A., Lacovara, K.J., 2016. Ichnological evidence for endobenthic response to the K-Pg event, New Jersey, U.S.A. Palaios, 31: 231-241.

Wilmsen, M., Uličný, D., Koš ák, M., 2014. Cretaceous basins of Central Europe: deciphering effects of global and regional processes - a short introduction. Zeitschrift der Deutschen Geologischen Gesellschaft, 165: 495-499.

Woelkerling, W.J., 1985. A taxonomic reassessment of Spongites (Corallinaceae, Rhodophyta) based on studies of Kützing's original collections. British Phycological Journal, 20: 123-153.

Woodward, S., 1830. A Synoptic Table of British Organic Remains. London \& Norwich.

Zittel, K.A. von, 1881-1885. Handbuch der Palaeontologie. 1 Abteilung, Palaeozoologie, 2, Oldenburg (München, Leipzig). 